Review

\title{
Berry color variation in grapevine as a source of diversity
}

\author{
Vanessa Ferreira $^{\mathrm{a}, \mathrm{b}, *}$, Olinda Pinto-Carnide ${ }^{\mathrm{a}}$, Rosa Arroyo-García ${ }^{\mathrm{b}}$, Isaura Castro ${ }^{\mathrm{a}}$ \\ ${ }^{\text {a }}$ Centre for the Research and Technology of Agro-Environmental and Biological Sciences (CITAB), University of Trás-os-Montes and Alto Douro, 5000-801 Vila Real, \\ Portugal \\ ${ }^{\mathrm{b}}$ Centre for Plant Biotechnology and Genomics (UPM-INIA, CBGP), Campus de Montegancedo, Autovía M40 km38, 28223 Pozuelo de Alarcón, Madrid, Spain
}

\section{A R T I C L E I N F O}

\section{Keywords:}

Vitis vinifera $\mathrm{L}$.

Spontaneous variation

Berry color

Phenolic compounds

MYBA genes

\begin{abstract}
A B S T R A C T
Even though it is one of the oldest perennial domesticated fruit crops in the world, grapevine (Vitis vinifera L.) cultivation today is the result of both conventional breeding practices (i.e. hybridizations adopted during the last century) and vegetative propagation. Human-assisted asexual propagation has allowed the maintenance of desired traits but has largely impacted the frequency of spontaneous somatic mutations observed in the field. Consequently, many grapevine fruit attributes to date have been artificially selected, including: fruit yield, compactness, size and composition, the latter being greatly diversified in the pursuit of altering berry skin coloration. The present review provides an overview of various aspects related to grapevine diversity, with a special emphasis on grape berry skin color variation and will discuss the current knowledge of how grape skin color variation is affected by the synthesis of phenolic compounds, particularly anthocyanins and their underlying genetic factors. We hope this knowledge will be useful in supporting the importance of the berry color trait diversity in cultivated grapevines, which is used as basis for selection during breeding programs because of its application for vine growers, winemakers and consumers.
\end{abstract}

\section{Introduction}

Grapevine (Vitis vinifera L.) is one of the most valuable agricultural crops worldwide and has been an integral part of human history since its domestication about 6000-8000 years ago (McGovern et al., 2017). This species is a member of the Vitaceae family, with Vitis being the only species of important economic interest, due mainly to its use as table grapes or for processing into wine (Galet, 1988; Levadoux et al., 1962; This et al., 2006).

During the domestication process of the wild Vitis vinifera subsp. sylvestris to Vitis vinifera subsp. sativa, a complex and long-term evolutionary process led to dramatic changes in grape morphology and physiology. Consequently, the resulting variability in several important traits has contributed to the large phenotypic diversity that is found in the cultivated grapevine nowadays (Terral et al., 2010; This et al., 2006). In response to different selective pressures, cultivar diversification has clearly occurred in several fruit traits (color, flavor, seedlessness). However, for some of these traits, the biological relevance and/or understood meaning of this variability still remains unclear (Cabezas et al., 2006; Emanuelli et al., 2010; Fournier-Level et al., 2010; This et al., 2006).

From early times, vine growers have selected the grapevine phenotypes capable of ensuring a greater and more regular fruit production and quality, maintaining them through vegetative propagation (Bacilieri et al., 2013). Although vegetative propagation has been used as a strategy for multiplication of plants with desired features, natural crossings between the newly introduced cultivars and the local germplasm also occurred along with the emergence of somatic mutation events (Pelsy, 2010). Somatic mutations that affect berry skin color leading to various phenotypes have been one of the major contributors for the current diversity in cultivated grapevines. Indeed, several pigmented varieties with certified clones with different color shades are currently known, such as, cv. 'Aramon', cv. 'Grenache', cv. 'Pinot' and cv. 'Terret'. Moreover, white-skinned varieties, such as cv. 'Savagnin', cv. 'Chardonnay' and cv. 'Chasselas' also comprise pigmented clones (Pelsy et al., 2015).

Research on grape berry color demonstrates that in white-skinned cultivars the absence of anthocyanins is related with the insertion of the Gret1, a long retrotransposon, in the promotor region of MYBA1 gene, combined with two non-conservative mutations in the coding sequence of MYBA2 gene (Fournier-Level et al., 2010; Lijavetzky et al., 2006). Additionally, several molecular and cellular mechanisms have been described as being behind berry skin color reversions occurring on grape varieties, which is linked to the phenolic profiles, specifically

\footnotetext{
* Corresponding author. Centre for the Research and Technology of Agro-Environmental and Biological Sciences (CITAB), University of Trás-os-Montes and Alto Douro, 5000-801 Vila Real, Portugal.

E-mail address: vanessa.cm.ferreira29@gmail.com (V. Ferreira).
} 
with the anthocyanin profile of the cultivars and ultimately with the skin color phenotype diversity.

The present review provides a general overview of grapevine diversity, with an emphasis on the berry skin color phenotype as a source of diversity, highlighting the phenolic compounds that determine this trait in grapevines and their underlying genetic factors.

\section{Grapevine origin and domestication}

Vitis vinifera $\mathrm{L} .(2 \mathrm{n}=38)$ belongs to the family Vitaceae, which comprises about 60 inter-fertile wild Vitis species distributed in Asia, North America and Europe under subtropical, Mediterranean and continental temperate climatic conditions (Galet, 1988; Levadoux et al., 1962). It is the single Vitis species that has acquired significant economic interest over time; some other species, for example the North American V. rupestris, $V$. riparia or $V$. berlandieri, are used as breeding rootstock due to their resistance against grapevine pathogens such as phylloxera [Daktulosphaira vitifoliae (Fitch)], oidium [Uncinula necator (Schw.) Burr] and mildews. Indeed, a great majority of the cultivars widely cultivated for fruit, juice and mainly for wine, classified as Vitis vinifera L. subsp. vinifera (or sativa), derive from wild forms [Vitis vinifera L. subsp. sylvestris (Gmelin) Hegi] (This et al., 2006), an event estimated to have occurred approximately 22,000 years ago. Since then, the cultivated form has suffered a steady decline in the effective population size, probably resulting from low-intensity management by humans before the domestication (Zhou et al., 2017). Data based on morphological differentiation and genetic relationships between wild and cultivated grapes has suggested the existence of at least two origins for the cultivated germplasm, one in the Near East and another in the western Mediterranean region (Arroyo-García et al., 2006). Thus, it is accepted that during the process of grapevine dissemination, multiple events of domestication and spontaneous hybridizations appeared among selected individuals and local wild populations, revealing an important contribution of Vitis vinifera subsp. sylvestris from both the Near East and Eastern Europe to crop diversity.

Archeological and historical findings suggest that the primary domestication event, could have occurred around 4000-6000 BC in the Near-East region between the Black and Caspian seas (Myles et al., 2011; Terral et al., 2010; This et al., 2006). The first evidence of wine production is found in the northern Zagros mountains of Iran, dating around 5000-5400 BC (McGovern, 2003; McGovern et al., 1996).

From the primary domestication region, humans gradually spread the initial cultivars to adjacent regions in the central and southern Zagros mountains, Jordan Valley and Egypt (Myles et al., 2011; This et al., 2006). Further dispersal occurred, following the main Mediterranean civilizations, which conducted grapevine expansion to more distant Mediterranean regions like Crete, southern Greece, both coasts of the Italian and Iberian peninsulas and the north of Africa. Under the influence of the Roman Empire this culture was expanded inland, mainly through the main trade routes of the Rhine, Rhone, Danube and Garonne rivers and reached other European temperate regions (This et al., 2006). In the middle ages, the Catholic Church had a significant role in disseminating grape cultivation mainly through the crusades that aimed to spread their religion to new regions (Sefc et al., 2003; This et al., 2006). Moreover, the extension of Islam also contributed to the diffusion of grape viticulture (particularly table grape cultivars) to North of Africa, Iberian Peninsula and Middle East (Zinelabidine et al., 2010).

During the 16th century, missionaries introduced the European grapevines to America, with seeds and cuttings from their places of origin, such as France, Germany, Spain, Italy and Eastern Europe. Later, during the 19th century, cuttings were also imported to South Africa, Australia and New Zealand. After millennia of global expansion, in the mid nineteenth-century, different disease-causing agents brought from America reached to Europe, particularly the phylloxera aphid, leading to a drastic change in the genetic diversity in the European vineyards with impacts to the present days. European viticulture was saved from extinction through the introduction of some non-vinifera species as rootstocks (indigenous from Eastern North America), which have a natural resistance to phylloxera and other soil-born problems that are not present in the European grapevines (This et al., 2006). In the 60's and 70's of 20th century, French grapevine varieties, such as cv. 'Chardonnay', cv. 'Cabernet Sauvignon', cv. 'Syrah' or cv. 'Merlot', were introduced in large numbers in the in the viticulture of the new world countries due to the perception of wine quality associated with French wine denominations (This et al., 2006). A recent study focused on the basis of grapevine genotype $\times$ environment $(G \times E)$ interactions showed that, for example, the cv. 'Cabernet Sauvignon' was less dependent on growth conditions and that its transcriptome remained more stable across vintages and locations, suggesting that the limited plasticity of this French cultivar may underpin its success in many different parts of the globe (Dal Santo et al., 2018; Paim Pinto et al., 2016).

\section{Spontaneous variation in grapevine}

\subsection{The role of naturally occurring mutations and human selection on grapevine diversity}

During the domestication and selection processes the biology of grapes underwent several dramatic changes that led to a significant divergence in important traits, contributing to the large phenotypic diversity found nowadays in cultivated grapevines. One of the most important events during domestication was the appearance of hermaphrodite flowers, removing the necessity to maintain both male and female wild plants (This et al., 2006). Additionally, cultivar diversification as a response to different selective pressures was clearly observed for berry color (Fournier-Level et al., 2010), Muscat flavor (Emanuelli et al., 2010) or table grape seedlessness (Cabezas et al., 2006). Other traits also appear to have been modified through domestication, such as seed size, leaf size and morphology, although their biological significance is not completely understood (This et al., 2006).

A few decades ago the number of different cultivars held in germplasm collections around the world was estimated at approximately 10.000 (Alleweldt and Dettweiler, 1994), a large number that included several synonyms (different names for the same cultivar) and homonyms (identical name for different cultivars). The current estimation of the number of different grapevine cultivars is around 5.000, being many of them being closely related. Information on the origin, main use and pedigree of these cultivars can be found on the Vitis International Catalogue (VIVC, http://www.vivc.de), which is a valuable tool to easily compare molecular fingerprints.

Genetic diversity has long been studied in grapevine with different sets of molecular markers (Castro et al., 2016, 2012; 2011; Ferreira et al., 2015), which has provided partial views of the genetic relationships among cultivated and wild germplasm, as well as on the expansion and evolution of domesticates (This et al., 2006). Although self-pollination is the major mating system in grapevine (Jackson, 2008), a primary conclusion of genetic diversity studies found that some cultivars were derived by spontaneous hybridizations from other existing cultivars. The first demonstrated case was cv. 'Cabernet Sauvignon', shown to be a spontaneous hybrid from the cross between $\mathrm{cv}$. 'Cabernet Franc' and cv. 'Sauvignon Blanc' (Bowers and Meredith, 1997). In fact, the probable reason why cultivars from a given region seem to be more closely related than to cultivars from other regions (Sefc et al., 2000) is because they have close family relationships.

Moreover, the current globalization of wine markets has focused only on a small number of highly appreciated cultivars of both white (cv. 'Chardonnay', cv. 'Sauvignon Blanc') and red cultivars (cv. 'Cabernet Sauvignon', cv. 'Syrah' and cv. 'Merlot'), and the demand for healthy disease-free plant material has led to a drastic reduction of diversity in the cultivated grapevine. Consequently, most of the 
traditional and local cultivars have almost disappeared, and some of those cultivars are only found in germplasm collections (This et al., 2006).

As stated before, human activity has played a pivotal role in shaping the existing diversity of grapes. In fact, most of the today's cultivars do not have a deliberate origin as they are the result of different processes of selection on certain grapevine genotypes that spontaneously occurred in nature. Since early times, vine growers have selected grapevine phenotypes capable of ensuring a greater and more regular fruit production and quality, and maintained them through vegetative propagation - a process which is believed to have been used since the beginning of the domestication process (Bacilieri et al., 2013).

Despite the importance of vegetative propagation as a conservation strategy to maintain desired phenotypes as genetically identical clones of the original donor plant (i.e. true-to-type), somatic mutations may naturally occur during plant growth and accumulate over time. Consequently, this somatic mutation might lead to a slightly different genotype and eventually to a different phenotype on a specific plant of the same cultivar, leading to clonal polymorphism. The new generated clone can be vegetatively propagated retaining the selected genetic and morpho-physiological difference, giving rise to a new cultivar (Pelsy, 2010). From the start of grapevine domestication, vegetative propagation combined with somatic variation have been widely exploited by vine growers to improve the phenotypic features of classic cultivars, representing a valuable source of diversity (This et al., 2006).

Higher plants have stratified apical meristems with layers of dividing cells that are characterized by different ontologies. Each cell layer develops independently from the adjacent layers, leading to the different plant tissues within an organ (Neilson-Jones, 1969). Thompson and Olmo (1963) proposed that the shoot apical meristem (SAM) of grapevine is composed of two different cell layers, L1 forming the epidermis and L2 making up most of the other parts of the plant, including mesophyll cells and gametes.

Somatic variation results from mutational events during plant development in a single cell that belongs to a specific shoot apical meristem cell layer. This mutated cell can then propagate by mitotic division, leading to the emergence of a mutated section and giving rise to a chimera. Such structures are specific types of genetic mosaic in which one or two entire cell layers of the apical meristem are genetically distinct from the others and remain developmentally independent from the adjacent layers. According to their spatial patterning, chimeras can be classified in the following three types: mericlinal, sectorial and periclinal. Mericlinal chimeras comprise a mutation in just a part of one tissue layer. Sectorial chimeras contain a mutation in a section of several layers and periclinal chimeras have a mutation in one or more entire layers (Fig. 1) (Dermen, 1960).

Briefly, somatic mutations can be propagated to the whole plant by a two-step process. First, a somatic mutation emerges in one cell of the shoot apical meristem, and is then propagated by cell division to an entire cell layer, generating a stable chimeric structure. Afterwards, the replacement of one cell layer by another can lead to a homogenization of the genotype of the whole plant, representing the second step of the process (Hocquigny et al., 2004). Due to the low level of organization of cell division in the inner layers, the most common cellular rearrangement observed is the invasion of the outer L1 layer by cells from the inner layer. Although rare, the opposite phenomenon, L1 cell invasion of the inner layer, is also accepted (Pelsy, 2010).

In grapevine, somatic variation occurs with relative frequency and is described as quite a common phenomenon. Despite the fact that mutation frequencies and rates are still relatively unknown, the reversion from the chimeric to the original status seems to occur more frequently than the opposite, maybe due to the unstable nature of the chimeras (reviewed in Pelsy, 2010; Torregrosa et al., 2011). Indeed, several variant traits have been described, including for berry color or flavor, date of ripening, canopy growth, size and compactness of bunches or productivity (Fig. 1, Table 1).
Some cultivars are known to be more prone to exhibit somatic polymorphisms than others. The basis for the wide range of clones in some cultivars could be genetic, due to a more unstable genetic background, but also the reflex of a longer history of cultivation or growth at a large extension, in which the age of the genotype should be considered, as well as the total area planted in different vineyards around the world to produce different wines with specific oenological characteristics (Pelsy et al., 2015; Torregrosa et al., 2011).

As an example, the 'Pinot' group typifies clonal phenotypic diversity, being one of the most ancient grapevine varieties made up of a large panel of clones (Pelsy et al., 2015). This great diversity of clones, which is due to spontaneous somatic mutations that have occurred over time is manifested in traits such as berry skin color (cv. 'Pinot Noir', cv. 'Pinot Gris' and cv. 'Pinot Blanc'), flesh pigmentation (cv. 'Pinot Teinturier'), yield level (cv. 'Pinot Fin' versus cv. 'Pinot Moyen'), leaf morphology (cv. 'Pinot Meunier'), canopy growth (cv. 'Pinot Detroit') and absence of wax on berries (cv. 'Pinot Moure').

At the genetic level, clonal polymorphism can result from singlenucleotide polymorphisms (SNPs), variations of SSR (Simple Sequence Repeat) length and insertion or deletion (INDELs) events.

The cultivar 'Pinot Meunier', a periclinal somatic variant of cv. 'Pinot Noir', shows an increase of trichomes on the leaf surface, which could be the result of an ancient mutation occurring only in the L1 epidermal layer (Franks et al., 2002). Besides inflorescences instead of tendrils, an extreme dwarfism was also observed by the same authors in plants regenerated from cv. 'Pinot Meunier' L1 cell layer, whereas plants regenerated from L2 cell layer were tall and with normal glabrous leaves, similar to cv. 'Pinot Noir' phenotype. These variations were found to be genetically heritable and associated with a point mutation in GAI1 gene involved in the gibberellic acid signaling (Boss and Thomas, 2002). This mutation in the DELLA domain converts a leucine residue into a histidine, which seems to alter the gibberellin-response properties of the protein, resulting in a critical 'Pinot' L1 mutant phenotype.

The cv. 'Ugni Blanc' is another case of somatic variation that had a major importance on the understanding of the molecular mechanisms behind fleshy fruit morphogenesis. A fleshless berry $(F l b)$ somatic variant was described for this cultivar. Fernandez et al. (2013) showed that the fleshless phenotype is caused by an inverted-repeat transposable element in the promoter region of the PISTILLATA-like $(P I)$ gene, a gene that was shown to be drastically repressed after flower fertilization in previous grapevine studies (Dauelsberg et al., 2011; Poupin et al., 2007). The same authors also concluded that PI alteration causes its ectopic expression and that this effect is cell layer-specific. The abnormal PI expression after fertilization in the L2 cell layer of the Flb somatic variant and derived $F l b$ mutant plants abrogates flesh development by preventing the differentiation of the highly vacuolated cells that are characteristic of this mesocarp tissue. Moreover, when the mutation is also present in the L1 cell layer, fruit development cannot proceed normally, being blocked at fruit set.

\subsection{Color variation as a consequence of chimerism}

The clonal polymorphism affecting berry skin color is the most wellstudied polymorphism leading to various phenotypes, having been intensively investigated in different grapevine varieties (Ferreira et al., 2018, 2016; Giannetto et al., 2008; Migliaro et al., 2014).

The occurrence of chimeric structures (with three or four-allele genotypes) has been detected by using microsatellite markers in a wide range of varieties, including cv. 'Primitivo' (Franks et al., 2002), cv. 'Greco di Tufo' and cv. 'Corvina Veronese' (Crespan, 2004), cv. 'Cabernet Sauvignon' (Moncada et al., 2006) or cv. 'Pinot' (Hocquigny et al., 2004). A certain locus presenting three alleles in one individual can be explained by a chimeric structure consisting of two cell layers with genotypes combining one common and one specific allele of each layer, whereas a four-allele locus is due to two completely different 

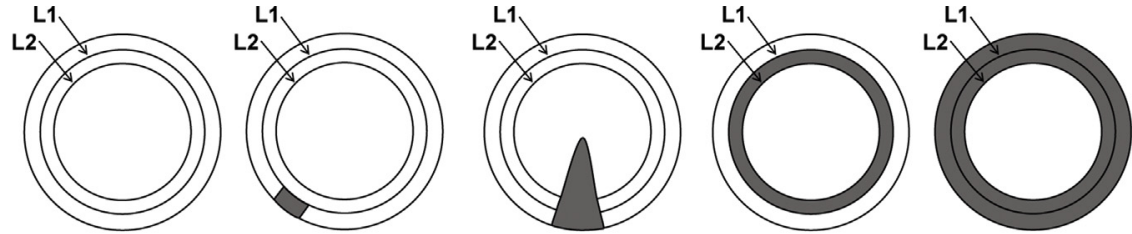

Non-mutated

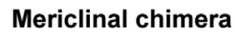

Sectorial chimera Periclinal chimera

\section{Solid mutant}

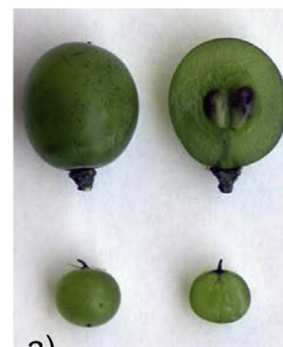

a)
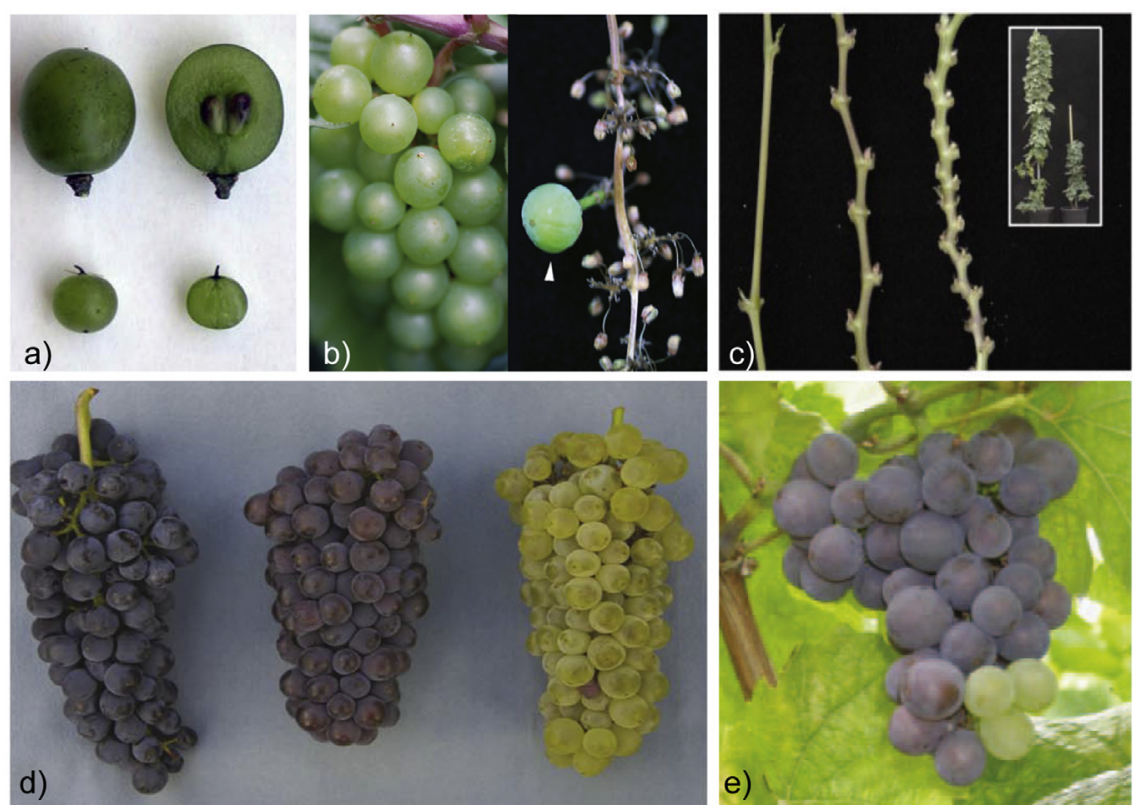

Fig. 1. Somatic variation in grapevine. Top: Diagram representing the three types of chimeras (Mericlinal, Sectorial and Periclinal) classified according to their spatial patterning [Adapted from Torregrosa et al. (2011)]. Bottom: Examples of mutant phenotypes of different varieties. a) 'Corinto Bianco' and its seedless mutant; b) 'Ugni Blanc' and its fleshless mutant; c) Dwarfism phenotype of 'Pinot Meunier'; d) 'Pinot Noir' and its grey and white-skinned color variants; e) White-skinned berries variegation in 'Pinot Gris' bunch [Adapted from Boss and Thomas (2002); This et al. (2006); Vargas et al. (2007); Pelsy (2010)]. (For interpretation of the references to color in this figure legend, the reader is referred to the Web version of this article.) genotypes in each layer.

The certified clone PG52 of cv. 'Pinot Gris' showed a triallelic profile at VVS2 microsatellite loci (126:134:148) (Hocquigny et al., 2004). Self-progenies of this clone produced only white-berried plants carrying two alleles (126:134), whereas plants regenerated from the L1 cell layer produced black berries with a different genotype (134:148). Thus, the grey-colored berry phenotype of PG52 clone could result from a chimeric structure, comprised of a colored L1 epidermis and L2 cells with a mutation that prevents anthocyanin synthesis, where the [134] allele at locus VVS2 is the common allele of both cell layers and the [148] and

Table 1

- Described variants for some of the most well-known international grapevine varieties [Adapted from Pelsy (2010)].

\begin{tabular}{|c|c|c|c|c|}
\hline Varietal group & Variants & Phenotype & Clonality ascertaining & References \\
\hline \multirow[t]{3}{*}{ Cabernet Sauvignon } & Cabernet Sauvignon & Black-skinned berries & & \\
\hline & Malian & Bronze-skinned berries & Bud sport of Cabernet Sauvignon & Boss et al. (1996); Walker et al. (2006) \\
\hline & Shalistin & White-skinned berries & Bud sport of Malian & \\
\hline \multirow[t]{3}{*}{ Chardonnay } & Chardonnay Blanc & White-skinned berries/neutral aroma & & \\
\hline & Chardonnay Muscaté & Rosy-skinned berries/aromatic & 16 SSRS & Duchêne et al. (2009) \\
\hline & Chardonnay Rose & Rosy-skinned berries/neutral aroma & Bud sport of Chardonnay Blanc & This et al. (2007) \\
\hline \multirow[t]{5}{*}{ Italia } & Italia & Green-skinned berries & & \\
\hline & Ruby Okuyama & Light-rosy-skinned berries & Bud sport of Italia & Kobayashi et al. (2004) \\
\hline & Rubi & Light-rosy-skinned berries & Bud sport of Italia & de Oliveira Collet et al. (2005) \\
\hline & Benitaka & Rosy-skinned berries & Bud sport of Italia & Azuma et al. (2009) \\
\hline & Brasil & Black-skinned and red-fleshed berries & Bud sport of Benitaka & de Oliveira Collet et al. (2005) \\
\hline \multirow[t]{3}{*}{ Muscat d'Alexandria } & Muscat d'Alexandria & White-skinned berries & & \\
\hline & Flame Muscat & Red-skinned berries & Bud sport of Muscat d'Alexandria & Kobayashi et al. (2004) \\
\hline & Zibibbo Nero & Red-skinned berries & Bud sport of Muscat d'Alexandria & De Lorenzis et al. (2015) \\
\hline \multirow[t]{5}{*}{ Pinot } & Pinot Noir & Glabrous leaves/black waxed berries & & \\
\hline & Pinot Moure & No wax berries & 50 SSR & Hocquigny et al. (2004) \\
\hline & Pinot Meunier & Hairy leaves and dwarfism & 50 SSR & Franks et al. (2002) \\
\hline & Pinot Gris & Red-grey-skinned berries & Bud sport of Pinot Noir & Vezzulli et al. (2012) \\
\hline & Pinot Blanc & White-skinned berries & Bud sport of Pinot Noir & Vezzulli et al. (2012) \\
\hline \multirow[t]{4}{*}{ Savagnin } & Savagnin blanc & White-skinned berries/neutral aroma & & \\
\hline & Savagnin & Rosy-skinned berries/neutral aroma & 16 SSR & Duchêne et al. (2009) \\
\hline & Rose & & & \\
\hline & Gewurztraminer & Rosy-skinned berries/aromatic & 16 SSR & \\
\hline \multirow[t]{2}{*}{ Ugni Blanc } & Ugni Blanc & Fleshy berries & & \\
\hline & Fleshless mutant & Fleshless berries & Bud sport of Ugni blanc & Fernandez et al. (2006) \\
\hline \multirow[t]{2}{*}{ Pedro Ximenes } & Pedro Ximenes & Seeded berries & & \\
\hline & Corinto Bianco & Seedless berries & 20 SSR & Vargas et al. (2007) \\
\hline
\end{tabular}


[126] alleles are specific to the L1 and L2 cell layers, respectively. Moreover, PG52 clone occasionally produces colored berries with white variegations. The colored skin sector was found to have the tri-allele profile, identical to the leaf at the VVS2 locus, whereas the white skin sector showed the diallelic combination transmitted to the self-progenies. A displacement from the L2 cell layer to the L1 could be responsible for generating the white-berried sector on cv. 'Pinot Gris' berries. Such displacements can affect a few berries or a whole bunch on a cane, according to the development stage during which the displacement occurs (Pelsy, 2010).

Moreover, the lack of anthocyanin pigments in the white-skinned phenotype has been associated with the insertion of Gret1 retrotransposon in the promoter region of MYBA1 gene combined with two non-conservative mutations in the coding sequence of $M Y B A 2$, a point mutation and a dinucleotide deletion (Kobayashi et al., 2004; Walker et al., 2007), both regulating the transcription of UFGT (UDP-glucose: flavonoid 3-O-glucosyltransferase), a key point in the anthocyanin pathway.

It is now well established that the clonal difference between the black-skinned cv. 'Pinot Noir' and the green-yellow cv. 'Pinot Blanc' was caused by a large deletion, which removed the functional colored alleles of both MYBA genes that regulate pigment production. This mutation led to the emergence of the colorless phenotype observed in cv. 'Pinot Blanc'. In turn, the grey-skinned phenotype of cv. 'Pinot Gris' results from a chimeric structure generated by the two-step process described above, composed of a colored L1 epidermis and L2 cells with a mutation that prevents anthocyanin synthesis (Hocquigny et al., 2004; Walker et al., 2006; Yakushiji et al., 2006). More recently, through a structural dynamics study along chromosome 2, comprising 29 'Pinot' clones, Vezzulli et al. (2012) concluded that cv. 'Pinot blanc' is not a bud sport of cv. 'Pinot Gris', since deletions comprising MYBA genes have different lengths, ranging from $100 \mathrm{~kb}$ to $179 \mathrm{~kb}$ for cv. 'Pinot Blanc' clones and from $4202 \mathrm{~kb}-4350 \mathrm{~kb}$ in the L2 cell layer of cv. 'Pinot Gris'. Consequently, a 'Parallel Model' was proposed to explain the evolutionary events that led to the formation of 'Pinot' berry color somatic variants, where the black-skinned ancestor cv. 'Pinot Noir' gave rise to the grey-skinned (cv. 'Pinot Gris') and the white-skinned (cv. 'Pinot Blanc') berry variants independently (Fig. 2-A). This model was an important advance in the knowledge on the emergence of somatic color mutants within a variety. Before that the prevailing idea was that these variants arise sequentially, the so called 'Sequential Model', proposed by Walker et al. (2006), in which the black-skinned berry ancestor (cv. 'Cabernet Sauvignon') gave rise to a periclinal chimera, the bronze-skinned phenotype of $\mathrm{cv}$. 'Malian', through a deletion encompassing the functional alleles of MYBA1 and MYBA2 in the L2 cells, which in turn gave rise to the white-skinned phenotype of cv. 'Shalistin', as the result of a cellular rearrangement (or displacement) in cv. 'Malian' whereby the L2 cell layer (unpigmented phenotype) replaced the $\mathrm{L} 1$ cells (pigmented phenotype) (Fig. 2-B).

\section{Grapevine berry skin color: an important quality trait}

\subsection{Biochemical and genetic factors underlying berry skin color}

Grapevine berries are complex organs composed of three clearly distinguished parts, the exocarp (skin) and mesocarp (flesh), which together constitute the pericarp, and the seeds. Berry development follows a double sigmoid growth pattern with three distinct phases, two growth periods separated by a lag phase. The onset of ripening occurring at the end of the lag phase (a short period known as verison) represents a key point in berry development in which several important changes occur, including the initiation of sugar accumulation, berry softening, berry pigmentation driven by the synthesis of anthocyanins in red cultivars, catabolism of organic acids and flavor maturation (Hardie et al., 1996; Robinson and Davies, 2000).

In this sense, several compounds accumulate during grape development in pericarp, and their presence is responsible for many relevant agronomic traits for table and wine grape quality, namely berry crispness and firmness, aroma and taste-related traits. For instance, the ratio between sugar (glucose and fructose) and acid (malic and tartaric) content at harvest is important for the flavor in table grapes and for the production of quality wines (Lijavetzky et al., 2012). Moreover, berry coloration is also an important trait quality that is used as the basis for selection during breeding programs. The color description in grape is an important factor for market acceptance and is crucial for two main reasons: 1 ) impact on consumers of table grapes, since they generally prefer well pigmented grapes and 2) for winemakers in the management of product transformation. Especially for the latter, the evaluation of the phenolic compounds content, particularly anthocyanins, is extremely relevant (Rustioni et al., 2013).

Considering that color is such an important quality parameter in table grapes and wines, it is imperative to understand how berry coloration is affected by genetic factors that regulate phenolic compounds biosynthesis, particularly flavonoids and anthocyanins, as this knowledge will contribute to a more stable production of high-quality pigmented grapes (Azuma, 2018).

Phenolic compounds are synthesized from the amino acid phenylalanine through the phenylpropanoid pathway (Fig. 3), which is one of the most well-studied pathways in the plant kingdom, both at the enzymatic and regulatory levels. In grapes the synthesis of these compounds responds to specific developmental cues and to environmental factors, such as low temperature and light, which have a synergistic effect on their accumulation. Additionally, recent studies also make reference that this response seems to be cultivar-specific, namely regarding the effect of solar radiation on phenolic compounds accumulation. Since phenolic compounds also influence organoleptic properties of the berries (such as taste and color) and are associated with several beneficial attributes for human health, this highlights the importance of adding new knowledge on secondary metabolites in grapevine to help vine growers to develop new cultivation techniques to modify and improve grape quality and adapt to a changing climate (reviewed by Azuma, 2018; Flamini et al., 2013; Matus, 2016; Wong and Matus, 2017).

Among the different phenolic compounds that influence the quality of grapes and wines, flavonoids (C6-C3-C6 skeleton structure) and stilbenes (C6-C2-C6) are the most important ones. Flavonoids are one of the most abundant groups of compounds in grape berry and consist of a mixture of different glycosylated and acylated derivatives of flavonols, flavan-3-ols [when organized into polymers are called proanthocyanidins (PAs) or condensed tannins] and anthocyanins. Among these classes of flavonoids, flavonols and anthocyanins are the main pigments that determine the berry skin color in grapevine.

Flavonols are yellow pigments that contribute directly to the color of white wines, being masked by anthocyanins in the red wines, whereas anthocyanins are pigments responsible for the orange, pink, red, blue and purple color of the berry skin in colored grapes. However, there are also a few cultivars, called teinturier or dyed cultivars, that can accumulate anthocyanins in their flesh in parallel with the accumulation in the berry skin, such as cv. 'Alicante Bouschet', also called cv. 'Garnacha Tintorera' (He et al., 2010; Teixeira et al., 2013). Although the profile of these compounds is commonly used as a fingerprint for cultivar identification, different clones of the same variety may present different anthocyanin contents, which is related with the level of intravarietal diversity of each grape variety (Van Leeuwen et al., 2013).

Usually, the main representatives of flavonols in red grapes are quercetin-3-O-glucosides (dihydroxylated) followed by myricetin (trihydroxylated), whereas quercetin and kaempferol (monohydroxylated) derivatives constitute the major flavonol compounds in white grapes (Castillo-Muñoz et al., 2007; Mattivi et al., 2006). Moreover, other less abundant flavonols can be synthesized; isorhamnetin is the methylated form of quercetin, and laricitrin and syringetin are the methylated 


\section{A}

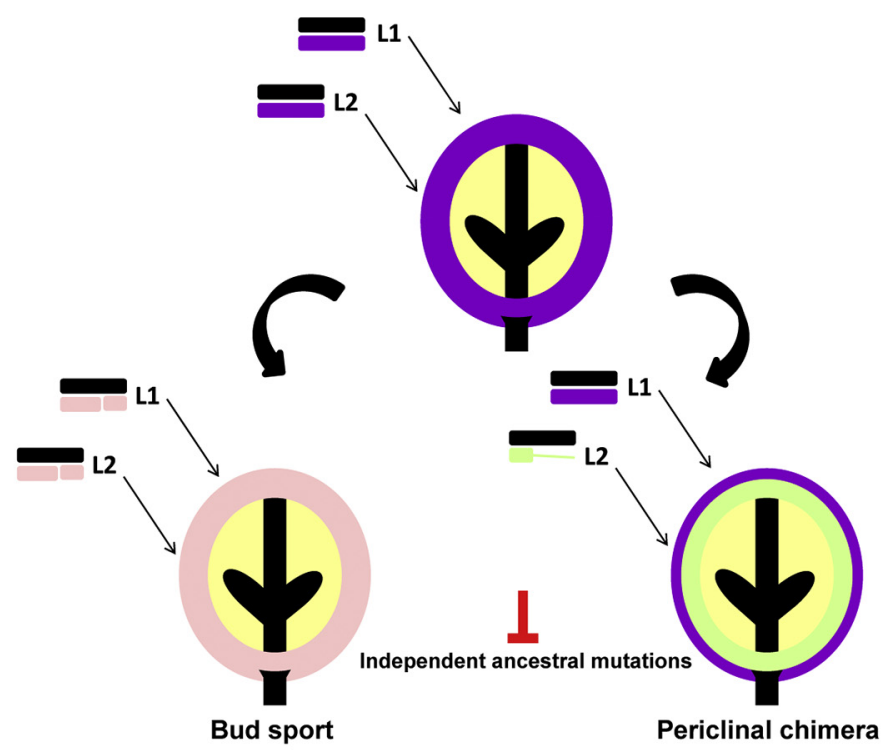

B

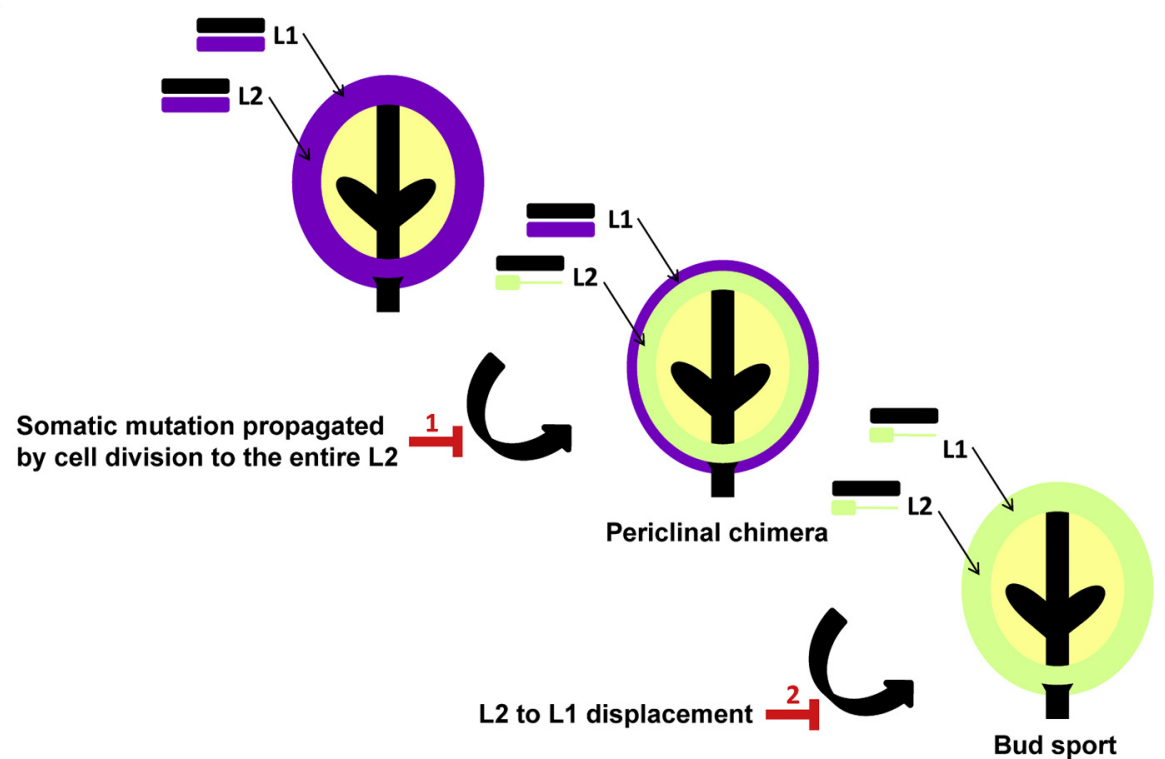

Fig. 2. Schematic representation of the evolutionary models that explain the development of somatic berry skin color mutants within a variety: Parallel model (A) and Sequential model (B) [Adapted from Ferreira et al. (2018)]. (For interpretation of the references to color in this figure legend, the reader is referred to the Web version of this article.)

forms of myricetin (Czemmel et al., 2017; Flamini et al., 2013; Teixeira et al., 2013). Regarding the quality of red wines, flavonols influence their color by means of copigmentation, a phenomenon that occurs due to molecular associations between anthocyanins and flavonols or other non-colored phenolic compounds (Castillo-Muñoz et al., 2010; Liang et al., 2011).

The genes coding for the enzymes of the flavonoid branch within the phenylpropanoid pathway are transcriptionally regulated by the combinatorial interaction between three classes of transcription factors (TFs): myeloblastosis (R2R3-MYB), basic helix-loop-helix (bHLH) and tryptophan-aspartic acid repeat protein (WDR or WD40) (Ramsay and Glover, 2005). A fourth class of TFs (WRKY) has been recently characterized in grapevine by Amato et al. (2017), who proposed WRKY26 as a putative regulator of vacuolar transport and acidification. Additionally, it was found that WRKY26 is also involved in the flavonoid pathway, showing a particular role in proanthocyanidin biosynthesis and deposition. In grapevine, the R2R3-MYB proteins family is currently understood to be composed of 134 genes (Wong et al., 2016) and is characterized as two highly conserved DNA binding domains and a variant number of C-terminal motifs (Dubos et al., 2010). These genes have been related to phenylpropanoid regulation and are thought to have expanded by gene duplication (Matus et al., 2008).

Although the initial regulatory mechanism of the first flavonol branch target gene flavonol synthase 1 (FLS1 or FLS4) by the R2R3MYB transcription factor MYBF1 is well-established, it is unclear how the high diversity of flavonol compounds found in grapes is achieved. Until recently, only two structural genes had been identified as involved in flavonol modification, namely GT5 and GT6, which encode a UDPglucuronic acid: flavonol-3-O-glucuronosyltransferase and a double functional UDP-glucose/UDP-galactose: flavonol-3-O-glucosyltransferase/galactosyltransferase, respectively (Ono et al., 2010). However, Czemmel et al. (2017) identified other promising novel flavonol biosynthetic genes, such as a flavonol glucosyltransferase (GT3) and a rhamnosyltransferase (RhaT1).

In addition, the anthocyanin content and composition, which are greatly affected by cultivar type and viticultural/environmental 


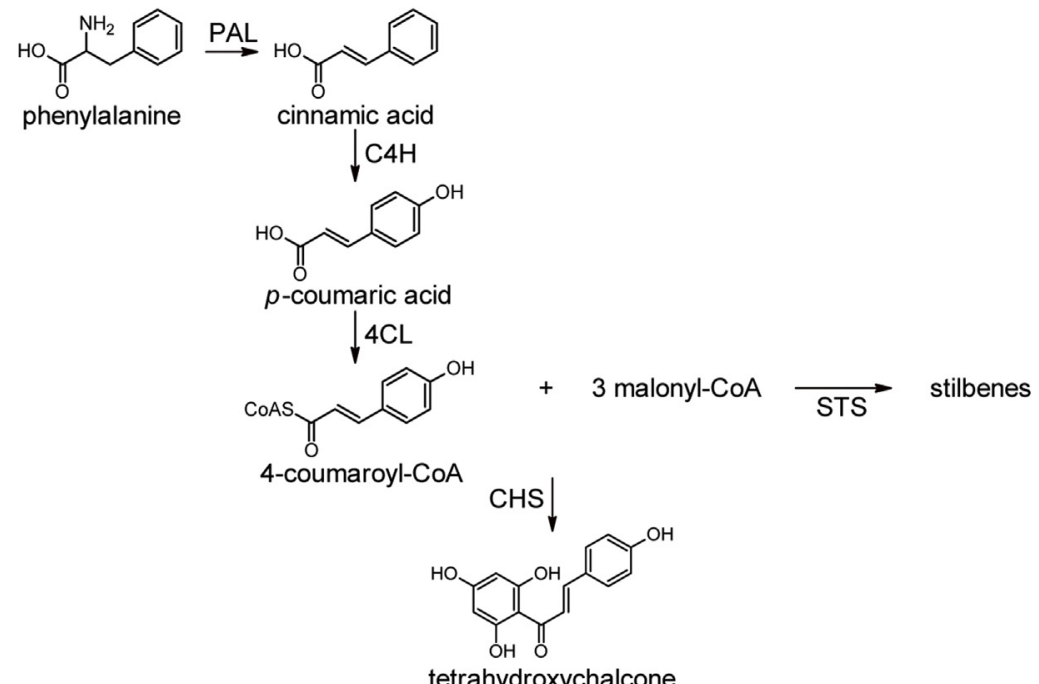

2)

tetrahydroxychalcone


H<smiles>[13BH][13CH3]</smiles>

F3'5'H

Pentahydroxyflavanone

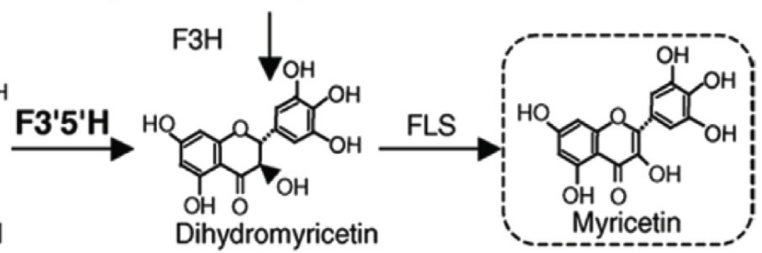

Dihydrokaempferol

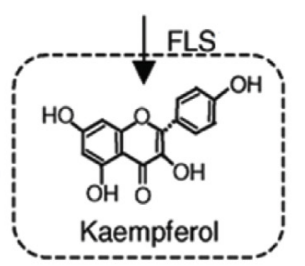

DFR $\downarrow$

Leucodelphinidin

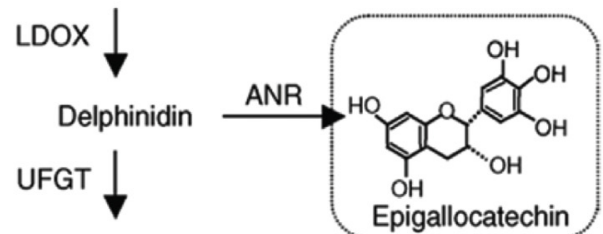

3)
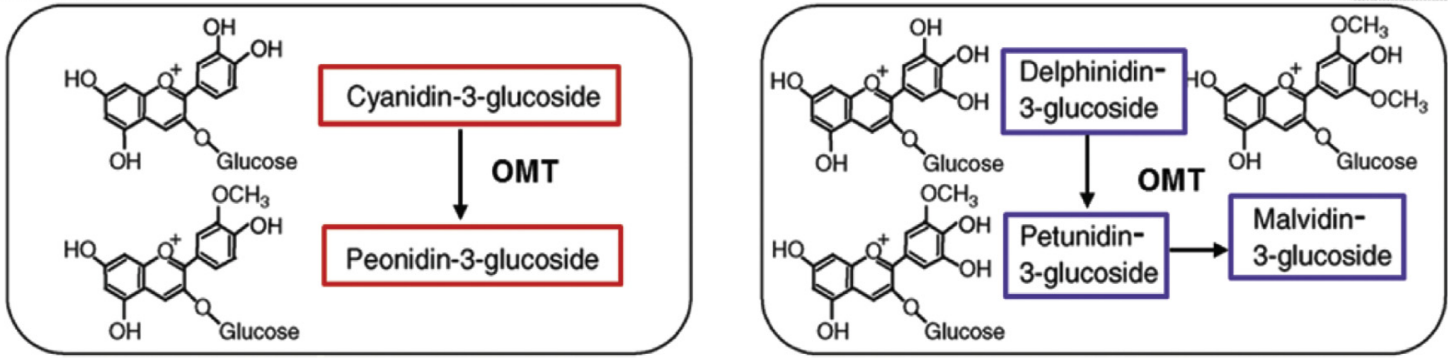

Fig. 3. Schematic representation of the main pathways involved in flavonoid biosynthesis in grapes. 1) general biosynthetic phenylpropanoid pathway. PAL, phenylalanine ammonia lyase; C4H, cinnamate-4-hydroxylase; 4CL, 4-coumaroyl: CoA-ligase; CHS, chalcone synthase; STS, stilbene synthase. 2) basic upstream flavonoid pathway leading to the biosynthesis of colored anthocyanidins. CHS, chalcone synthase; $\mathrm{CHI}$, chalcone isomerase; F3H, flavanone 3-hydroxylase; F3' $\mathrm{H}$, flavonoid 3'-hydroxylase; F3'5'H, flavonoid 3',5'-hydroxylase; DFR, dihydroflavonol 4-reductase; LDOX, leucoanthocyanidin dioxygenase. 3) Specific branch for the anthocyanin modification of free anthocyanidins. Colored boxes indicate the skin color produced by the five major anthocyanins (red boxes represent the dihydroxylated anthocyanins and purple boxes the tri-hydroxylated anthocyanins). UFGT, UDP-glucose:flavonoid 3-O-glucosyltransferase; OMT, $O$-methyltransferase [Adapted from Flamini et al. (2013) and Kuhn et al. (2014)]. (For interpretation of the references to color in this figure legend, the reader is referred to the Web version of this article.)

conditions, are also an important factor with a direct impact on color variation of grape berry skin, providing a huge assortment of colors ranging from whitish, yellow, green, to pink, grey, and to darker red, purple and black berries. These different color shades and hues are mainly influenced by the presence of five major anthocyanins in grape, which differ from each other in the number and positions of the hydroxyl and methoxyl groups on the B-ring (reviewed by He et al., 2010). Cyanidin and peonidin are dihydroxylated precursors of red anthocyanins, whereas delphinidin, petunidin and malvidin are trihydroxylated precursors of blue and purple (Fig. 3). In grape, anthocyanins are mainly present as 3-O-monoglucoside derivatives due to the presence of two disruptive mutations in the anthocyanin 5-O- 
Chr. 2

a)

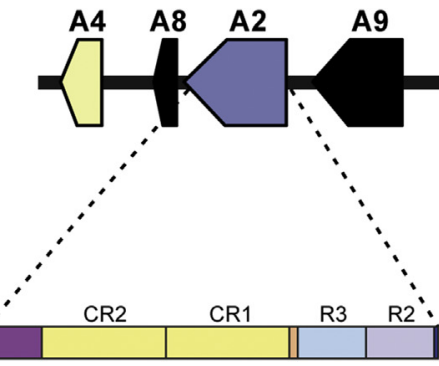

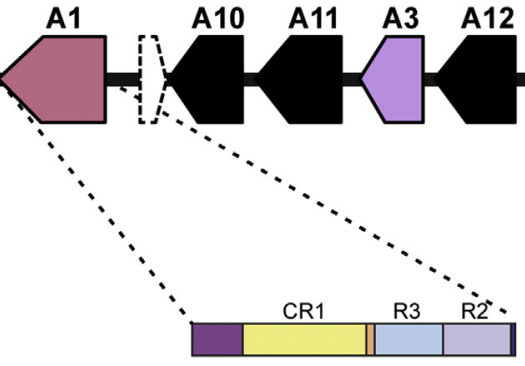

Fig. 4. The berry color locus on chromosome 2. a) Schematic representation of the anthocyanin-related MYBA genes as present in the grapevine genome of cv. 'Pinot Noir' PN 40024. All genes are displayed in the same orientation, mostly positioned in tandem, with the exception of MYBA1/MYBA10 that share the presence of a non- $M Y B$ gene between them. Gene sizes are represented to scale, but intergenic regions are not; b) Genomic organization of MYBA1 and MYBA2 protein variants. Each domain is shown with a specific color box, indicating that the MYB repeats are identical between the proteins, R2 and R3 DNA

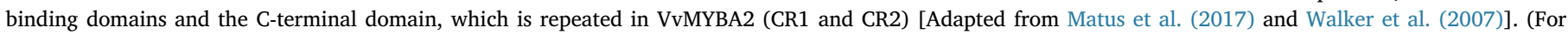
interpretation of the references to color in this figure legend, the reader is referred to the Web version of this article.) glucosyltransferase gene, which produces a non-functional form of the enzyme. Additionally, anthocyanins can also be acylated with aromatic and aliphatic acids as acetylmonoglucoside and $p$-coumaroylmonoglucoside derivatives.

The anthocyanin synthesis regulation is directly related with the activity of different R2R3-MYB transcription factors, some of which are located in two well-described grape color loci. The recently identified 'vegetative color locus' (Matus et al., 2017) harbors MYBA5/6 and MYBA7 genes (Chr. 14), while the 'berry color locus' comprises MYBA1 and MYBA2 genes (Chr. 2) (Walker et al., 2007), two essential genes that determine berry skin color variation (Fournier-Level et al., 2010). Both loci share the regulation of late biosynthetic and modification/ transport-related genes, such as UDP-glucose: flavonoid 3-O-glucosyltransferase (UFGT) and anthocyanin 3-O-glucoside-6"-O-acyltransferase (3AT) (Matus et al., 2017; Rinaldo et al., 2015; Walker et al., 2007). However, the synthesis of specific anthocyanins is also affected by the expression of early biosynthetic genes that encode flavonoid $3^{\prime}$ hydroxylase $\left(\mathrm{F}^{\prime} \mathrm{H}\right)$ and flavonoid $3^{\prime}, 5^{\prime}$-hydroxylase $\left(\mathrm{F}^{\prime} 5^{\prime} \mathrm{H}\right)$. These enzymes competitively control the synthesis of di- and trihydroxylated anthocyanins, respectively, whereas anthocyanin $O$-methyltransferase (AOMT) methylates anthocyanins of both groups. Usually $\mathrm{F}^{\prime} 5^{\prime} \mathrm{H}$ activity prevails over $\mathrm{F}^{\prime} \mathrm{H}$, and the products of flavonoid hydroxylases are predominately channeled into the branch of the pathway involved in the biosynthesis of delphinidin (blue purplish derivatives) at the expense of those involved in the synthesis of cyanidin (reddish derivatives) (Castellarin et al., 2006; Castellarin and Di Gaspero, 2007; Jeong et al., 2006). In contrast with the well-characterized MYBA1 gene, which promotes the synthesis of larger quantities of trihydroxylated anthocyanins, the vegetative color locus genes (MYBA6/7) are not able to activate the trihydroxylated branch due to the lack of a C-terminal protein motif that is present on MYBA1 and related genes of the berry color locus. Consequently, only dihydroxylated anthocyanins with a reddish hue are almost exclusively accumulated on the vegetative organs, both in black- and white-skinned cultivars (Matus et al., 2017). Additionally, anthocyanin synthesis is also induced by light and high sucrose levels (Yamakawa et al., 1983). More specifically, it has been shown that the DFR gene expression, which is higher after ripening onset (Boss et al., 1996), is induced by sucrose. Behind this regulation is the presence of two sucrose boxes on the gene promoter to which sugar can bind and activate gene expression (Gollop et al., 2002).

In summary, several members of the R2R3-MYB family have been characterized, many of which act as positive regulators of the synthesis of anthocyanins (MYBA1/A2, MYB5B, MYBA6 and MYBA7), proanthocyanidins (MYBPA1/PA2/PAR) and flavonols (MYBF1). Along with its role as an activator of flavonoid pathway structural genes (CHI, F3'5'H, ANS, LAR1 and ANR), MYB5B also regulates other processes such as vacuolar acidification and membrane remodeling (Cavallini et al., 2015). This is of particular relevance since, in other genera like Petunia, it has been shown that vacuolar $\mathrm{pH}$ affects the coloration of the synthesized anthocyanins. An increase in $\mathrm{pH}$ shifts the color from purple to blue in plant lines that synthesize malvidin or petunidin derivatives, or from red to a dull grey in a cyanidin background (Tornielli et al., 2009).

More recently, repressors of the accumulation of small weight phenolic acids and flavonoids (MYB4A) (Cavallini et al., 2015) and positive regulators of stilbenoid accumulation (MYB15 and MYB14) (Holl et al., 2013) have also been identified. The differential activation or repression of different steps of the pathway is responsible for restricting the anthocyanins accumulation to specific developmental stages and also in response to different environmental factors and agricultural practices (reviewed by Matus, 2016).

\subsection{The berry color locus: master regulator of berry skin color}

Skin color in grapes has become greatly diversified, showing different color shades as a result of hybridization and human selection. As stated above, the color of berry skin is mainly associated with the content and composition of anthocyanins, which is determined by the allelic status of a major locus that spans over a 200-kb region on chromosome 2 (Azuma et al., 2009; Fournier-Level et al., 2009; Matus et al., 2008). This berry color locus comprises a cluster of closely related R2R3-MYB genes and pseudogenes, among which the functional MYBA1 and MYBA2 genes, two adjacent transcription factors that regulate the transcription of UFGT (UDP-glucose:flavonoid 3-O-glucosyltransferase), represent the major genetic determinant of skin color variation., A third gene (MYBA3) has also been functionally tested but does not activate anthocyanin synthesis and the less related gene MYBA4 gene also does not seem to play a role in anthocyanin biosynthesis in grape berries (Fig. 4) (Walker et al., 2007).

The emergence of the colorless phenotype observed on the whiteskinned cultivars, a derived state that arose from the highly colored (less diverse and homozygous) wild ancestor. This resulted from the simultaneous occurrence of mutations in MYBA1 and MYBA2 genes, which cause the loss of transcription factor expression and, consequently, abrogate anthocyanin biosynthesis. Different combinatorial mutations on these two genes led to the emergence of not only the white-skinned phenotypes, but also to a range of pale-phenotypes, largely assessed in different genotypes and somatic variants (Ferreira et al., 2018, 2017; Lijavetzky et al., 2006; Migliaro et al., 2014). These were selected during the domestication process, favoring a rapid diffusion of the less colored phenotypes, leading to the diversification of berry color. Nowadays, both vine growers and winemakers take advantage of this color diversity to address consumer tastes in table grapes and wine.

The mutations on MYBA1 and MYBA2 genes can be grouped as summarized by Matus et al. (2017): (i) inactivation of MYBA1 through the insertion of the Gret1 retrotransposon in its promoter/5' untranslated region (5'-UTR) (Kobayashi et al., 2005, 2004); (ii) non-synonymous single-nucleotide polymorphism and a frame-shift mutation in the MYBA2 coding region (Walker et al., 2007); or (iii) a large deletion removing both $M Y B A 1$ and MYBA2 from the berry color locus (Walker et al., 2006; Yakushiji et al., 2006).

In more detail, the absence of anthocyanins in white-skinned cultivars has been largely associated with the insertion of the Gret1, a 
10,422 bp long gypsy-type retrotransposon, in the promoter region of MYBA1 gene, which leads to transcriptional inactivation. The presence of Gret1 retrotransposon in the promoter of the MYBA1 gene was first described and associated with a loss-of-function in cv. 'Italia' and cv. 'Muscat of Alexandria' cultivars resulting in the non-functional allele $V v m y b A 1^{I T A}$, also called VvmybA1a allele (Kobayashi et al., 2004). On the other hand, the most likely original sequence of $M Y B A 1$, before the Gret1 retrotransposon insertion, corresponds to the functional wild-type allele $V v m y b A 1^{A F L}$, commonly known as $V v m y b A 1 c$ allele, which completely lacks Gret1 (Yakushiji et al., 2006). Moreover, other MYBA1 functional alleles have been described, mainly associated with reversions from mutated-to-functional allelic versions. The partial Gret1 retrotransposon excision from the MYBA1 promoter leaving behind its solo-3'LTR region constitutes the $V v m y b A 1^{R U O}$ allele, also named $V v m y b A 1 b$. This allele has been firstly described on cv. 'Ruby Okuyama', which may have occurred as a result of intra-recombination between the 5'LTR and 3'LTR of Gret1 in the 5'-flanking region near the coding region of MYBA1, and its functional allele (Kobayashi et al., $2005,2004)$. Since then it has been identified in several red-skinned somatic variants derived from white-skinned cultivars, and described as the main mechanism responsible for color recovery on white-skinned cultivars (Ferreira et al., 2018; Migliaro et al., 2014).

In addition, the rosy-skinned somatic variant cv. 'Benitaka' derived from the white-skinned cv. 'Italia' is caused by the appearance of the functional allele $V v m y b A 1^{B E N}$, which was reported as a result of homologous recombination between the promoter regions of the nonfunctional allele of MYBA1 $\left(V v m y b^{I T A}\right.$ ) and MYBA3, resulting in the restoration of MYBA1 transcripts on cv. 'Benitaka' (Azuma et al., 2009). Furthermore, a less frequent functional allele, called $V v m y b A 1^{S U B}$, was also observed in some cultivars, as the result of three short insertions, two in the 5'-UTR region (111- and 44-bp) and one in the second intron (33-bp) (Lijavetzky et al., 2006; This et al., 2007).

Regarding MYBA2 gene polymorphisms, Walker et al. (2007) reported that MYBA2 can be inactivated by two non-conservative mutations, one leading to an amino acid substitution (change of arginine residue at position 44 in the red allele [G] to leucine in the white allele [T], within the first MYB repeat) and the other to a frame shift resulting in a smaller protein (a 2-bp deletion [CA] was found altering the reading frame at the amino acid position 258 ). The non-functional allele of this gene was named $V v m y b A 2 w$, while the functional allele was called VvmybA2r.

Walker et al. (2007) reported that Vvmyb1w (equivalent to Vvmy$b A 1^{I T A}$ ) and $V v m y b A 2 w$, and $V v m y b A 1 r$ (equivalent to $V v m y b A 1^{A F L}$ ) and $V v m y b A 2 r$, were closely linked on the same chromosome, and named them the white and red alleles, respectively. Since these two adjacent $M Y B$ alleles in the berry color locus are inherited together, it is helpful to consider them as part of a single MYB haplotype (Azuma et al., 2008, 2009). Based on the detection of $V v m y b A 1^{I T A}$ and $V v m y b A 1^{A F L}$, it was first thought that haplotype A (Hap A, equivalent to the white allele) corresponds to a non-functional 'white' haplotype, containing both nonfunctional alleles $V v m y b A 1^{I T A}$ and $V v m y b A 2 w$ and that haplotype C (Hap C, equivalent to the red allele) corresponds to the 'colored' haplotype. Later on, Fournier- Level et al. (2010) reported that Hap C could be divided into two subgroups: Hap $\mathrm{C}-\mathrm{N}$ and Hap C-Rs. Hap $\mathrm{C}-\mathrm{N}$ is presumed to be the ancestral MYB haplotype, containing the functional $V v m y b A 1^{A F L}$ and $V v m y b A 2 r$ alleles and Hap C-Rs contains the functional $V v m y b A 1^{A F L}$ and the non-functional VvmybA2w (Fig. 5).

Taking into account this haplotype structure, it seems that the Gret1 insertion in the MYBA1 promoter region occurred after the emergence of $V v m y b A 2 w$. Other $M Y B$ haplotypes have been identified, namely by Walker et al. (2006) and Yakushiji et al. (2006) who showed that the skin color mutation responsible for changing black-skinned cv. 'Pinot Noir' to white-skinned cv. 'Pinot Blanc' is caused by deletion of the $V v m y b A 1^{A F L}$ and $V v m y b A 2 r$ alleles in Hap $\mathrm{C}-\mathrm{N}$, resulting in the nonfunctional Hap D, which contains null alleles both at the MYBA1 (called $V v m y b A 1^{P N B}$ allele) and MYBA2 loci (Fig. 5) (Azuma et al., 2008).
Furthermore, Hap B seems to be originated from Hap A since it contains the alleles $V v m y b A 1^{R U O}$ (resulting from intra-recombination between the 5'LTR and 3'LTR of Gret1 in the 5'-flanking region near the coding region of MYBA1) and VvmybA2w (Fig. 5).

The color recovery in rosy-skinned cv. 'Benitaka', a bud sport of the white-skinned cv. 'Italia' (Hap A/Hap A), is caused by the appearance of the functional $V v m y b B A 1^{B E N}$ allele at the MYBA1 locus, due to homologous recombination between the promoter regions of the non-functional allele of MYBA1 and MYBA3, as mentioned earlier (Azuma et al., 2009). The occurrence of this allelic combination, $V v m y b A 1^{B E N}$ and $V v m y b A 2 w$, at the color locus gave rise to a new functional haplotype called Hap G (Fig. 5) (Azuma, 2018).

Several genetic studies have revealed that white-skinned cultivars are homozygous for non-functional Hap A (Hap A/Hap A), whereas color-skinned cultivars contain at least one functional haplotype (Azuma et al., 2007; Kobayashi et al., 2004; Lijavetzky et al., 2006; This et al., 2007). Furthermore, it was also found that the $M Y B$ haplotype is a major genetic determinant of anthocyanin content in grape berry skin and several findings indicate that the combination of functional haplotypes at the color locus affects the quantity of anthocyanins. Thus, grape cultivars with two functional haplotypes have a higher anthocyanin content than those with only a single functional haplotype (Azuma et al., 2008, 2011; Ban et al., 2014; Song et al., 2014). A similar conclusion was made by Carrasco et al. (2015) which, despite having found new functional alleles in wild accessions, never observed in cultivated grapevine, showed that wild accessions carrying two functional haplotypes had higher anthocyanin levels than accessions with a single functional haplotype. Thus, the difference in potential anthocyanin accumulation between Hap $\mathrm{C}-\mathrm{N}$ and Hap C-Rs grapes can be explained by the number of functional $M Y B$ alleles in each haplotype. Hap $\mathrm{C}-\mathrm{N}$ has two functional alleles $\left(V v m y b A 1^{A F L}\right.$ and $\left.V v m y b A 2 r\right)$, whereas Hap C-Rs has only one (VvmybA1 $\left.{ }^{A F L}\right)$.

The $M Y B$ haplotype composition at the berry color locus is also a major genetic factor that determines the anthocyanin composition, since it has been demonstrated that the number and kind of functional MYB haplotypes affects the ratios of tri-to dihydroxylated anthocyanins and of methylated to non-methylated anthocyanins (Azuma, 2018). This has been demonstrated by Azuma et al. (2009), who showed that the two colored bud sports of the white-skinned cv. 'Italia' (Hap A/Hap A), the red-skinned cv. 'Ruby Okuyama' (Hap A/Hap B) and the rosyskinned cv. 'Benitaka' (Hap A/Hap G) in addition to having different MYB haplotype composition also have different anthocyanins content and composition. The cv. 'Ruby Okuyama' has predominantly dihydroxylated non-methylated anthocyanins, whereas cv. 'Benitaka' has predominantly methylated anthocyanins and a moderate amount of trihydroxylated anthocyanins, which is also reflected by a $F 3^{\prime} 5^{\prime} H / F 3^{\prime} H$ expression ratio and much higher AOMT expression in cv. 'Benitaka' than in cv. 'Ruby Okuyama'.

\section{Conclusions}

Grapevine has a highly diversified phenotypic variation and some key features affect desired attributes for grape growers, not only in regard to crop yield, but also quality-related features, such as the color of the berry skin. Berry skin color is one of the most important evolutionary traits and a prime factor contributing to grape quality and subsequent market value. This major quality-trait is mainly determined by the quantity and composition of anthocyanins, and decreased grape quality has recently been associated with the poor coloration of redberried cultivars. Considering the worldwide commercial importance of grapes, this review provides a useful overview of the current knowledge about the genetic control of anthocyanin biosynthesis, contributing to a more comprehensive understanding of the metabolic and genetic factors that control grape skin color.

During the last decade, several studies related with grape skin color have shown that R2R3-MYB gene structure and composition at the color 


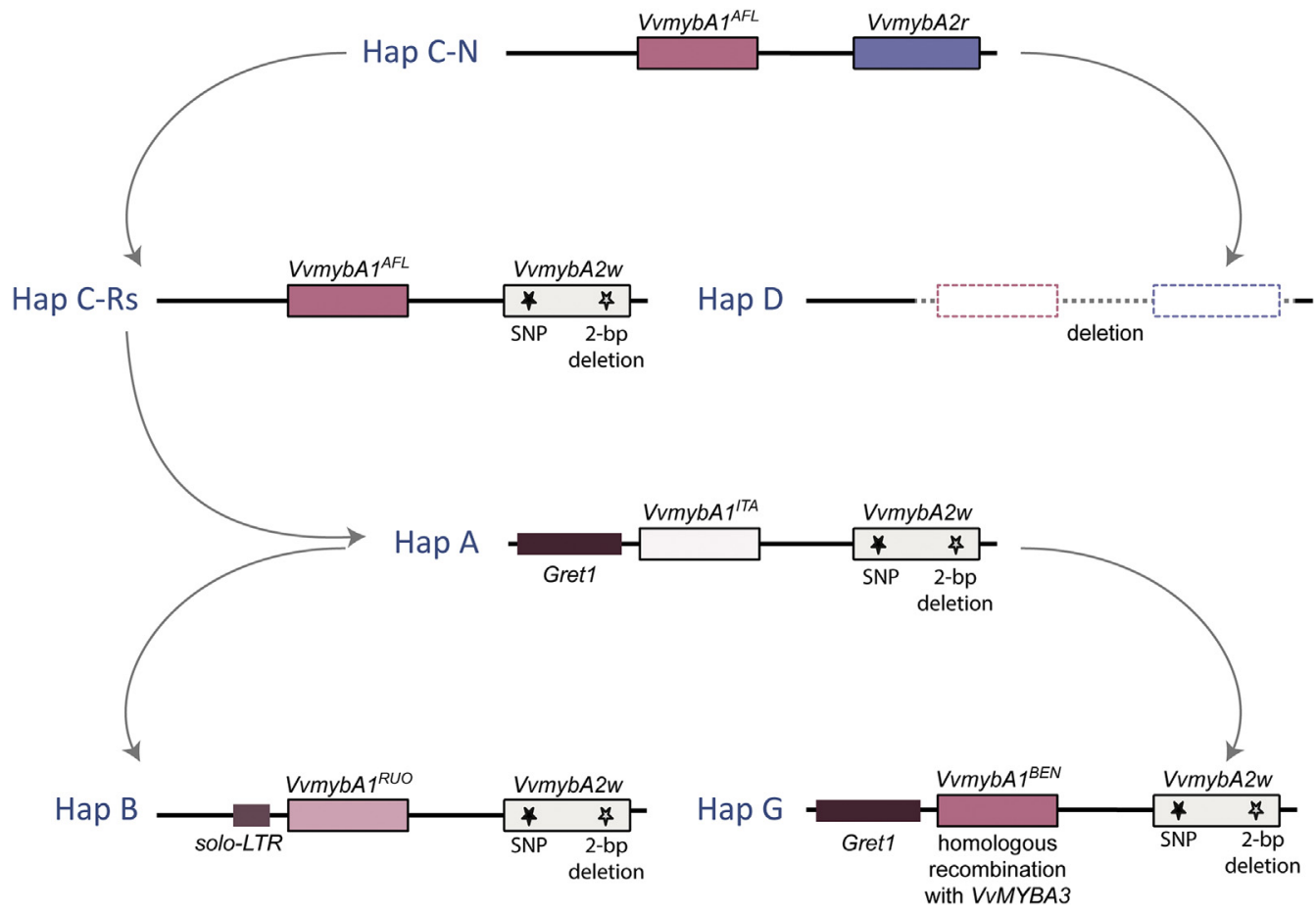

Fig. 5. Schematic representation of the evolutionary differentiation of the main MYBA haplotypes at the color locus in grapevine [Adapted from Lacombe (2012) and Azuma (2018)]. (For interpretation of the references to color in this figure legend, the reader is referred to the Web version of this article.)

locus is the major genetic determinant of the anthocyanin content and composition in grape berry skin. However, these genes might be single parts of a highly complex network. In this sense, the multi-omics data integration (genomics, transcriptomics, proteomics, metabolomics) allows to building complex maps of molecular regulation and interaction. In grapevine, network analyses have mostly been adopted to infer about gene function and coordinated biological processes related to plant metabolism, namely the regulatory mechanisms that control berry composition (reviewed by Wong and Matus, 2017). Recently, Vannozzi et al. (2018) took advantage of the integrated network analysis and identified transcription factors of different families, including WRKYs that are putatively involved in the regulation of the grapevine STS multigenic family, along with the R2R3-MYB family (MYB13, MYB14 and MYB15) (Wong et al., 2016). In this way, these studies could bring knowledge regarding new anthocyanin regulators, which may act as singular effectors in the activation of structural genes or through a combinatorial affect and play a major role in the synthesis of these compounds.

\section{Contribution}

Vanessa Ferreira: Designed the work and wrote the manuscript.

Olinda Pinto-Carnide, Rosa Arroyo-García and Isaura Castro: Revised the manuscript and gave suggestions to improve it.

\section{Acknowledgements}

This work was supported by European Investment Funds through FEDER/COMPETE/POCI - Operational Competitiveness and Internationalization Programme, under Project POCI-01-0145-FEDER006958, and National Funds by FCT - Portuguese Foundation for Science and Technology, under the project UID/AGR/04033/2013. V. Ferreira is also indebted to FCT for her grant (SFRH/BD/96400/2013). Work in R. Arroyo-García lab is funded by the INIA Project RTA201400016-C02-01.

\section{References}

Alleweldt, G., Dettweiler, E., 1994. The Genetic Resources of Vitis: World List of Grapevine Collections, second ed. (Geilweilerhof).

Amato, A., Cavallini, E., Zenoni, S., Finezzo, L., Begheldo, M., Ruperti, B., Tornielli, G.B., 2017. A grapevine TTG2-like WRKY transcription factor is involved in regulating vacuolar transport and flavonoid biosynthesis. Front. Plant Sci. 7, 1-20. https://doi. org/10.3389/fpls.2016.01979.

Arroyo-García, R., Ruiz-García, L., Bolling, L., Ocete, R., López, M. a, Arnold, C., Ergul, a, Söylemezoğlu, G., Uzun, H.I., Cabello, F., Ibáñez, J., Aradhya, M.K., Atanassov, a, Atanassov, I., Balint, S., Cenis, J.L., Costantini, L., Goris-Lavets, S., Grando, M.S., Klein, B.Y., McGovern, P.E., Merdinoglu, D., Pejic, I., Pelsy, F., Primikirios, N., Risovannaya, V., Roubelakis-Angelakis, K. a, Snoussi, H., Sotiri, P., Tamhankar, S., This, P., Troshin, L., Malpica, J.M., Lefort, F., Martinez-Zapater, J.M., Ruiz-Garcia, L., Lopez, M.A., Soylemezoglu, G., Ibanez, J., 2006. Multiple origins of cultivated grapevine (Vitis vinifera L. ssp. sativa) based on chloroplast DNA polymorphisms. Mol. Ecol. 15, 3707-3714. https://doi.org/10.1111/j.1365-294X.2006.03049.x.

Azuma, A., 2018. Genetic and environmental impacts on the biosynthesis of anthocyanins in grapes. Horticulture J. https://doi.org/10.2503/hortj.OKD-IR02.

Azuma, A., Kobayashi, S., Goto-Yamamoto, N., Shiraishi, M., Mitani, N., Yakushiji, H., Koshita, Y., 2009. Color recovery in berries of grape (Vitis vinifera L.) 'Benitaka', a bud sport of 'Italia', is caused by a novel allele at the VvmybA1 locus. Plant Sci. 176, 470-478. https://doi.org/10.1016/j.plantsci.2008.12.015.

Azuma, A., Kobayashi, S., Mitani, N., Shiraishi, M., Yamada, M., Ueno, T., Kono, A. Yakushiji, H., Koshita, Y., 2008. Genomic and genetic analysis of Myb -related genes that regulate anthocyanin biosynthesis in grape berry skin. Theor. Appl. Genet. 117, 1009-1019. https://doi.org/10.1007/s00122-008-0840-1.

Azuma, A., Kobayashi, S., Yakushui, H., Yamada, M., Mitani, N., Sato, A., 2007. VvmybA1 genotype determines grape skin color. Vitis 46, 154-155.

Azuma, A., Udo, Y., Sato, A., Mitani, N., Kono, A., Ban, Y., Yakushiji, H., Koshita, Y., Kobayashi, S., 2011. Haplotype composition at the color locus is a major genetic determinant of skin color variation in Vitis $\times$ labruscana grapes. Theor. Appl. Genet. 122, 1427-1438. https://doi.org/10.1007/s00122-011-1542-7.

Bacilieri, R., Lacombe, T., Le Cunff, L., Di Vecchi-Staraz, M., Laucou, V., Genna, B., Péros, J.-P., This, P., Boursiquot, J.-M., 2013. Genetic structure in cultivated grapevines is linked to geography and human selection. BMC Plant Biol. 13, 25. https://doi.org/10. 1186/1471-2229-13-25.

Ban, Y., Mitani, N., Hayashi, T., Sato, A., Azuma, A., Kono, A., Kobayashi, S., 2014. Exploring quantitative trait loci for anthocyanin content in interspecific hybrid grape (Vitis labruscana $\times$ Vitis vinifera). Euphytica 198, 101-114. https://doi.org/10. 1007/s10681-014-1087-3.

Boss, P.K., Davies, C., Robinson, S.P., 1996. Analysis of the expression of anthocyanin pathway genes in developing Vitis vinifera L. cv Shiraz grape berries and the implications for pathway regulation. Plant Physiol. 111, 1059-1066. https://doi.org/ 10.1104/pp.111.4.1059.

Boss, P.K., Thomas, M.R., 2002. Association of dwarfism and floral induction with a grape "green revolution" mutation. Nature 416, 847-850. https://doi.org/10.1038/ 
416847a.

Bowers, J.E., Meredith, C.P., 1997. The parentage of a classic wine grape, Cabernet Sauvignon. Nat. Genet. 16, 84-87. https://doi.org/10.1038/ng0597-84.

Cabezas, J.A., Cervera, M.T., Ruiz-García, L., Carreño, J., Martínez-Zapater, J.M., 2006. A genetic analysis of seed and berry weight in grapevine. Genome 49, 1572-1585. https://doi.org/10.1139/g06-122.

Carrasco, D., De Lorenzis, G., Maghradze, D., Revilla, E., Bellido, A., Failla, O., ArroyoGarcía, R., 2015. Allelic variation in the VvMYBA1 and VvMYBA2 domestication genes in natural grapevine populations (Vitis vinifera subsp. sylvestris). Plant Systemat. Evol. 301, 1613-1624. https://doi.org/10.1007/s00606-014-1181-y.

Castellarin, S., Di Gaspero, G., Marconi, R., Nonis, A., Peterlunger, E., Paillard, S., AdamBlondon, A.-F., Testolin, R., 2006. Colour variation in red grapevines (Vitis vinifera L.): genomic organisation, expression of flavonoid 3'-hydroxylase, flavonoid 3',5'hydroxylase genes and related metabolite profiling of red cyanidin-/blue delphinidinbased anthocyanins in berry skin. BMC Genom. 7, 12. https://doi.org/10.1186/14712164-7-12.

Castellarin, S.D., Di Gaspero, G., 2007. Transcriptional control of anthocyanin biosynthetic genes in extreme phenotypes for berry pigmentation of naturally occurring grapevines. BMC Plant Biol. 7, 46. https://doi.org/10.1186/1471-2229-7-46.

Castillo-Muñoz, N., Gómez-Alonso, S., García-Romero, E., Hermosín-Gutiérrez, I., 2010. Flavonol profiles of Vitis vinifera white grape cultivars. J. Food Compos. Anal. 23, 699-705. https://doi.org/10.1016/j.jfca.2010.03.017.

Castillo-Muñoz, N., Gómez-Alonso, S., García-Romero, E., Hermosín-Gutiérrez, I., 2007. Flavonol profiles of Vitis vinifera red grapes and their single-cultivar wines. J. Agric. Food Chem. 55, 992-1002. https://doi.org/10.1021/jf062800k.

Castro, I., D'Onofrio, C., Martín, J.P., Ortiz, J.M., De Lorenzis, G., Ferreira, V., PintoCarnide, O., 2012. Effectiveness of AFLPs and retrotransposon-based markers for the identification of Portuguese grapevine cultivars and clones. Mol. Biotechnol. 52, 26-39. https://doi.org/10.1007/s12033-011-9470-y.

Castro, I., Martín, J.P., Ortiz, J.M., Pinto-Carnide, O., 2011. Varietal discrimination and genetic relationships of Vitis vinifera L. cultivars from two major Controlled Appellation (DOC) regions in Portugal. Sci. Hortic. (Amst.) 127, 507-514. https:// doi.org/10.1016/j.scienta.2010.11.018.

Castro, I., Pinto-Carnide, O., Ortiz, J.M., Ferreira, V., Martín, J.P., 2016. A comparative analysis of genetic diversity in Portuguese grape germplasm from ampelographic collections fit for quality wine production. Spanish J. Agric. Res. 14https://doi.org/ 10.5424/sjar/2016144-8852. e0712.

Cavallini, E., Matus, J.T., Finezzo, L., Zenoni, S., Loyola, R., Guzzo, F., Schlechter, R., Ageorges, A., Arce-Johnson, P., Tornielli, G.B., 2015. The phenylpropanoid pathway is controlled at different branches by a set of R2R3-MYB C2 repressors in grapevine. Plant Physiol. 167, 1448-1470. https://doi.org/10.1104/pp.114.256172.

Crespan, M., 2004. Evidence on the evolution of polymorphism of microsatellite markers in varieties of Vitis vinifera L. Theor. Appl. Genet. 108, 231-237. https://doi.org/10. 1007/s00122-003-1419-5.

Czemmel, S., Höll, J., Loyola, R., Arce-Johnson, P., Alcalde, J.A., Matus, J.T., Bogs, J., 2017. Transcriptome-wide identification of novel UV-B- and light modulated flavonol pathway genes controlled by VviMYBF1. Front. Plant Sci. 8, 1-15. https://doi.org/ $10.3389 /$ fpls.2017.01084

Dal Santo, S., Zenoni, S., Sandri, M., De Lorenzis, G., Magris, G., De Paoli, E., Di Gaspero, G., Del Fabbro, C., Morgante, M., Brancadoro, L., Grossi, D., Fasoli, M., Zuccolotto, P., Tornielli, G.B., Pezzotti, M., 2018. Grapevine field experiments reveal the contribution of genotype, the influence of environment and the effect of their interaction $(\mathrm{G} \times \mathrm{E})$ on the berry transcriptome. Plant J. 93, 1143-1159. https://doi.org/10.1111/ tpj.13834.

Dauelsberg, P., Matus, J.T., Poupin, M.J., Leiva-Ampuero, A., Godoy, F., Vega, A., ArceJohnson, P., 2011. Effect of pollination and fertilization on the expression of genes related to floral transition, hormone synthesis and berry development in grapevine. J. Plant Physiol. 168, 1667-1674. https://doi.org/10.1016/j.jplph.2011.03.006.

De Lorenzis, G., Squadrito, M., Brancadoro, L., Scienza, A., 2015. Zibibbo nero characterization, a red-wine grape revertant of muscat of Alexandria. Mol. Biotechnol. 57, 265-274. https://doi.org/10.1007/s12033-014-9820-7.

de Oliveira Collet, S.A., Collet, M.A., Machado, M. de F.P.S., 2005. Differential gene expression for isozymes in somatic mutants of Vitis vinifera L. (Vitaceae). Biochem. Systemat. Ecol. 33, 691-703. https://doi.org/10.1016/j.bse.2004.12.016.

Dermen, H., 1960. Nature of plant sports. Am. Hortic. Mag. 39, 123-173.

Dubos, C., Stracke, R., Grotewold, E., Weisshaar, B., Martin, C., Lepiniec, L., 2010. MYB transcription factors in Arabidopsis. Trends Plant Sci. 15, 573-581. https://doi.org/ 10.1016/j.tplants.2010.06.005.

Duchêne, E., Legras, J.L., Karst, F., Merdinoglu, D., Claudel, P., Jaegli, N., Pelsy, F., 2009. Variation of linalool and geraniol content within two pairs of aromatic and nonaromatic grapevine clones. Aust. J. Grape Wine Res. 15, 120-130. https://doi.org/ 10.1111/j.1755-0238.2008.00039.x.

Emanuelli, F., Battilana, J., Costantini, L., Le Cunff, L., Boursiquot, J.-M., This, P., Grando, M.S., 2010. A candidate gene association study on muscat flavor in grapevine (Vitis vinifera L.). BMC Plant Biol. 10, 241. https://doi.org/10.1186/1471-2229-10-241.

Fernandez, L., Doligez, A., Lopez, G., Thomas, M.R., Bouquet, A., Torregrosa, L., 2006. Somatic chimerism, genetic inheritance, and mapping of the fleshless berry ( flb ) mutation in grapevine ( Vitis vinifera L.). Genome 49, 721-728. https://doi.org/10. 1139/g06-034.

Fernandez, L., Chäib, J., Martinez-Zapater, J.M., Thomas, M.R., Torregrosa, L., 2013. Misexpression of a PISTILLATA-like MADS box gene prevents fruit development in grapevine. Plant J. 73, 918-928. https://doi.org/10.1111/tpj.12083.

Ferreira, V., Castro, I., Carrasco, D., Pinto-Carnide, O., Arroyo-García, R., 2018. Molecular characterization of berry skin color reversion on grape somatic variants. J. Berry Res. 8, 147-162. https://doi.org/10.3233/JBR-170289.

Ferreira, V., Fernandes, F., Carrasco, D., Hernandez, M.G., Pinto-Carnide, O., Arroyo-
García, R., Andrade, P., Valentão, P., Falco, V., Castro, I., 2017. Spontaneous variation regarding grape berry skin color: a comprehensive study of berry development by means of biochemical and molecular markers. Food Res. Int. 97, 149-161. https:// doi.org/10.1016/j.foodres.2017.03.050.

Ferreira, V., Fernandes, F., Pinto-Carnide, O., Valentão, P., Falco, V., Martín, J.P., Ortiz, J.M., Arroyo-García, R., Andrade, P.B., Castro, I., 2016. Identification of Vitis vinifera L. grape berry skin color mutants and polyphenolic profile. Food Chem. 194, 117-127. https://doi.org/10.1016/j.foodchem.2015.07.142.

Ferreira, V., Pinto-Carnide, O., Mota, T., Martín, J.P., Ortiz, J.M., Castro, I., 2015 Identification of minority grapevine cultivars from Vinhos Verdes Portuguese DOC region. Vitis 54, 53-58.

Flamini, R., Mattivi, F., De Rosso, M., Arapitsas, P., Bavaresco, L., 2013. Advanced knowledge of three important classes of grape phenolics: anthocyanins, stilbenes and flavonols. Int. J. Mol. Sci. 14, 19651-19669. https://doi.org/10.3390/ ijms141019651.

Fournier-Level, A., Lacombe, T., Le Cunff, L., Boursiquot, J.-M.M., This, P., 2010. Evolution of the VvMybA gene family, the major determinant of berry colour in cultivated grapevine (Vitis vinifera L.). Heredity 104, 351-362. https://doi.org/10. 1038/hdy.2009.148.

Fournier-Level, A., Le Cunff, L., Gomez, C., Doligez, A., Ageorges, A., Roux, C., Bertrand, Y., Souquet, J.-M.M., Cheynier, V., This, P., 2009. Quantitative genetic bases of anthocyanin variation in grape (Vitis vinifera L. ssp. sativa) berry: a quantitative trait locus to quantitative trait nucleotide integrated study. Genetics 183, 1127-1139. https://doi.org/10.1534/genetics.109.103929.

Franks, T., Botta, R., Thomas, M.R., Franks, J., 2002. Chimerism in grapevines: implications for cultivar identity, ancestry and genetic improvement. Theor. Appl. Genet. 104, 192-199. https://doi.org/10.1007/s001220100683.

Galet, P., 1988. In: Cépages et vignobles de France. Tome 1. Les vignes américaines, 2ème, (Montpellier, France).

Giannetto, S., Velasco, R., Troggio, M., Malacarne, G., Storchi, P., Cancellier, S., De Nardi, B., Crespan, M., 2008. A PCR-based diagnostic tool for distinguishing grape skin color mutants. Plant Sci. 175, 402-409. https://doi.org/10.1016/j.plantsci.2008.05.010.

Gollop, R., Even, S., Colova-Tsolova, V., Perl, A., 2002. Expression of the grape dihydroflavonol reductase gene and analysis of its promoter region. J. Exp. Bot. 53, 1397-1409. https://doi.org/10.1093/jexbot/53.373.1397.

Hardie, W.J., Brien, T.P.O., Jaudzems, V.G., 1996. Morphology , anatomy and development of the pericarp after anthesis in grape, Vitis vinifera L. Aust. J. Grape Wine Res. 2, 97-142. https://doi.org/10.1111/j.1755-0238.1996.tb00101.x.

He, F., Mu, L., Yan, G.-L., Liang, N.-N., Pan, Q.-H., Wang, J., Reeves, M.J., Duan, C.-Q., 2010. Biosynthesis of anthocyanins and their regulation in colored grapes. Molecules 15, 9057-9091. https://doi.org/10.3390/molecules15129057.

Hocquigny, S., Pelsy, F., Dumas, V., Kindt, S., Heloir, M.-C., Merdinoglu, D., 2004. Diversification within grapevine cultivars goes through chimeric states. Genome 47, 579-589. https://doi.org/10.1139/g04-006.

Holl, J., Vannozzi, A., Czemmel, S., D'Onofrio, C., Walker, A.R., Rausch, T., Lucchin, M., Boss, P.K., Dry, I.B., Bogs, J., 2013. The R2R3-MYB transcription factors MYB14 and MYB15 regulate stilbene biosynthesis in Vitis vinifera. Plant Cell 25, 4135-4149. https://doi.org/10.1105/tpc.113.117127.

Jackson, R.S., 2008. Grapevine structure and function. In: Wine Science: Principles and Applications. Academic Press, San Diego, pp. 85

Jeong, S.T., Goto-Yamamoto, N., Hashizume, K., Esaka, M., 2006. Expression of the flavonoid 3'-hydroxylase and flavonoid 3',5'-hydroxylase genes and flavonoid composition in grape (Vitis vinifera). Plant Sci. 170, 61-69. https://doi.org/10.1016/j. plantsci.2005.07.025.

Kobayashi, S., Goto-Yamamoto, N., Hirochika, H., 2005. Association of VvmybA1 gene expression with anthocyanin production in grape (Vitis vinifera) skin-color mutants. J. Japanese Soc. Hortic. Sci. 74, 196-203. https://doi.org/10.2503/jjshs.74.196.

Kobayashi, S., Goto-Yamamoto, N., Hirochika, H., 2004. Retrotransposon-induced mutations in grape skin color. Science 304https://doi.org/10.1126/science.1095011. 982-982.

Kuhn, N., Guan, L., Dai, Z.W., Wu, B.-H., Lauvergeat, V., Gomès, E., Li, S.-H., Godoy, F., Arce-Johnson, P., Delrot, S., 2014. Berry ripening: recently heard through the grapevine. J. Exp. Bot. 65, 4543-4559. https://doi.org/10.1093/jxb/ert395.

Lacombe, T., 2012. Contribution à l'étude de l'histoire évolutive de la vigne cultivée (Vitis vinifera L .) par l'analyse de la diversité génétique neutre et de gènes d'intérêt. (Montpellier SupAgro).

Levadoux, L., Boubals, D., Rives, M., 1962. Le genre Vitis et ses espèces. Ann. Amélioration des Plantes 12, 19-44.

Liang, Z., Owens, C.L., Zhong, G.-Y., Cheng, L., 2011. Polyphenolic profiles detected in the ripe berries of Vitis vinifera germplasm. Food Chem. 129, 940-950. https://doi. org/10.1016/j.foodchem.2011.05.050.

Lijavetzky, D., Carbonell-Bejerano, P., Grimplet, J., Bravo, G., Flores, P., Fenoll, J., Hellín, P., Oliveros, J.C., Martínez-Zapater, J.M., 2012. Berry flesh and skin ripening features in Vitis vinifera as assessed by transcriptional profiling. PLoS One 7, e39547. https:// doi.org/10.1371/journal.pone.0039547.

Lijavetzky, D., Ruiz-García, L., Cabezas, J. a, De Andrés, M.T., Bravo, G., Ibáñez, A Carreño, J., Cabello, F., Ibáñez, J., Martínez-Zapater, J.M., 2006. Molecular genetics of berry colour variation in table grape. Mol. Genet. Genom. 276, 427-435. https:// doi.org/10.1007/s00438-006-0149-1.

Mattivi, F., Guzzon, R., Vrhovsek, U., Stefanini, M., Velasco, R., 2006. Metabolite profiling of grape: flavonols and anthocyanins. J. Agric. Food Chem. 54, 7692-7702. https://doi.org/10.1021/jf061538c.

Matus, J., Aquea, F., Arce-Johnson, P., 2008. Analysis of the grape MYB R2R3 subfamily reveals expanded wine quality-related clades and conserved gene structure organization across Vitis and Arabidopsis genomes. BMC Plant Biol. 8, 83. https://doi.org/ $10.1186 / 1471-2229-8-83$ 
Matus, J.T., 2016. Transcriptomic and metabolomic networks in the grape berry illustrate that it takes more than flavonoids to fight against ultraviolet radiation. Front. Plant Sci. 7, 1337. https://doi.org/10.3389/fpls.2016.01337.

Matus, J.T., Cavallini, E., Loyola, R., Höll, J., Finezzo, L., Dal Santo, S., Vialet, S., Commisso, M., Roman, F., Schubert, A., Alcalde, J.A., Bogs, J., Ageorges, A., Tornielli, G.B., Arce-Johnson, P., 2017. A group of grapevine MYBA transcription factors located in chromosome 14 control anthocyanin synthesis in vegetative organs with different specificities compared with the berry color locus. Plant J. 91, 220-236. https://doi.org/10.1111/tpj.13558.

McGovern, P., Jalabadze, M., Batiuk, S., Callahan, M.P., Smith, K.E., Hall, G.R., Kvavadze, E., Maghradze, D., Rusishvili, N., Bouby, L., Failla, O., Cola, G., Mariani, L., Boaretto, E., Bacilieri, R., This, P., Wales, N., Lordkipanidze, D., 2017. Early neolithic wine of Georgia in the South Caucasus. Proc. Natl. Acad. Sci. Unit. States Am. 114, E10309-E10318. https://doi.org/10.1073/pnas.1714728114.

McGovern, P.E., 2003. Ancient Wine. The Search for the Origins of Viniculture. Princeton University Press, Princeton, NJ.

McGovern, P.E., Glusker, D.L., Exner, L.J., Voigt, M.M., 1996. Neolithic resinated wine. Nature 381, 480-481. https://doi.org/10.1038/381480a0.

Migliaro, D., Crespan, M., Muñoz-Organero, G., Velasco, R., Moser, C., Vezzulli, S., 2014. Structural dynamics at the berry colour locus in $V$ itis vinifera L. somatic variants. Aust. J. Grape Wine Res. 20, 485-495. https://doi.org/10.1111/ajgw.12103.

Moncada, X., Pelsy, F., Merdinoglu, D., Hinrichsen, P., 2006. Genetic diversity and geographical dispersal in grapevine clones revealed by microsatellite markers. Genome 49, 1459-1472. https://doi.org/10.1139/g06-102.

Myles, S., Boyko, A.R., Owens, C.L., Brown, P.J., Grassi, F., Aradhya, M.K., Prins, B., Reynolds, A., Chia, J.-M., Ware, D., Bustamante, C.D., Buckler, E.S., 2011. Genetic structure and domestication history of the grape. Proc. Natl. Acad. Sci. U.S.A. 108, 3530-3535. https://doi.org/10.1073/pnas.1009363108.

Neilson-Jones, W., 1969. Plant Chimeras, second ed. Methuen, London.

Ono, E., Homma, Y., Horikawa, M., Kunikane-Doi, S., Imai, H., Takahashi, S., Kawai, Y., Ishiguro, M., Fukui, Y., Nakayama, T., 2010. Functional differentiation of the glycosyltransferases that contribute to the Chemical diversity of bioactive flavonol glycosides in grapevines (Vitis vinifera). Plant Cell 22, 2856-2871. https://doi.org/ $10.1105 /$ tpc. 110.074625 .

Paim Pinto, D.L., Brancadoro, L., Dal Santo, S., De Lorenzis, G., Pezzotti, M., Meyers, B.C., Pè, M.E., Mica, E., 2016. The influence of genotype and environment on small RNA profiles in grapevine berry. Front. Plant Sci. 7. https://doi.org/10.3389/fpls.2016. 01459.

Pelsy, F., 2010. Molecular and cellular mechanisms of diversity within grapevine varieties. Heredity 104, 331-340. https://doi.org/10.1038/hdy.2009.161.

Pelsy, F., Dumas, V., Bévilacqua, L., Hocquigny, S., Merdinoglu, D., 2015. Chromosome replacement and deletion lead to clonal polymorphism of berry color in grapevine. PLoS Genet. 11, e1005081. https://doi.org/10.1371/journal.pgen.1005081.

Poupin, M.J., Federici, F., Medina, C., Matus, J.T., Timmermann, T., Arce-Johnson, P., 2007. Isolation of the three grape sub-lineages of B-class MADS-box TM6, PISTILLATA and APETALA3 genes which are differentially expressed during flower and fruit development. Gene 404, 10-24. https://doi.org/10.1016/j.gene.2007.08. 005 .

Ramsay, N.A., Glover, B.J., 2005. MYB-bHLH-WD40 protein complex and the evolution of cellular diversity. Trends Plant Sci. 10, 63-70. https://doi.org/10.1016/j.tplants. 2004.12.011.

Rinaldo, A.R., Cavallini, E., Jia, Y., Moss, S.M.A., McDavid, D.A.J., Hooper, L.C., Robinson, S.P., Tornielli, G.B., Zenoni, S., Ford, C.M., Boss, P.K., Walker, A.R., 2015. A grapevine anthocyanin acyltransferase, transcriptionally regulated by VvMYBA, can produce most acylated anthocyanins present in grape skins. Plant Physiol. 169https://doi.org/10.1104/pp.15.01255. 1897-916.

Robinson, S.P., Davies, C., 2000. Molecular biology of grape berry ripening. Aust. J. Grape Wine Res. 6, 175-188. https://doi.org/10.1111/j.1755-0238.2000.tb00177.x.

Rustioni, L., Basilico, R., Fiori, S., Leoni, A., Maghradze, D., Failla, O., 2013. Grape colour phenotyping: development of a method based on the reflectance spectrum. Phytochem. Anal. 24, 453-459. https://doi.org/10.1002/pca.2434.

Sefc, K.M., Lopes, M.S., Lefort, F., Botta, R., Roubelakis-Angelakis, K.A., Ibáñez, J., Pejić, I., Wagner, H.W., Glössl, J., Steinkellner, H., 2000. Microsatellite variability in grapevine cultivars from different European regions and evaluation of assignment testing to assess the geographic origin of cultivars. Theor. Appl. Genet. 100, 498-505. https://doi.org/10.1007/s001220050065.

Sefc, K.M., Steinkellner, H., Lefort, F., Botta, R., Machado, A. da C., Borrego, J., Maletić, E., Glössl, J., 2003. Evaluation of the genetic contribution of local wild vines to European grapevine cultivars. Am. J. Enol. Vitic. 54, 15-21.
Song, S., del Mar Hernández, M., Provedo, I., Menéndez, C.M., 2014. Segregation and associations of enological and agronomic traits in Graciano $\times$ Tempranillo wine grape progeny (Vitis vinifera L.). Euphytica 195, 259-277. https://doi.org/10.1007/ s10681-013-0994-z.

Teixeira, A., Eiras-Dias, J., Castellarin, S.D., Gerós, H., 2013. Berry phenolics of grapevine under challenging environments. Int. J. Mol. Sci. 14, 18711-18739. https://doi.org/ 10.3390/ijms140918711.

Terral, J.-F., Tabard, E., Bouby, L., Ivorra, S., Pastor, T., Figueiral, I., Picq, S., Chevance, J.-B., Jung, C., Fabre, L., Tardy, C., Compan, M., Bacilieri, R., Lacombe, T., This, P., 2010. Evolution and history of grapevine (Vitis vinifera) under domestication: new morphometric perspectives to understand seed domestication syndrome and reveal origins of ancient European cultivars. Ann. Bot. 105, 443-455. https://doi.org/10. 1093/aob/mcp298.

This, P., Lacombe, T., Cadle-Davidson, M., Owens, C.L., 2007. Wine grape (Vitis vinifera L.) color associates with allelic variation in the domestication gene VvmybA1. Theor. Appl. Genet. 114, 723-730. https://doi.org/10.1007/s00122-006-0472-2.

This, P., Lacombe, T., Thomas, M.R., 2006. Historical origins and genetic diversity of wine grapes. Trends Genet. 22, 511-519. https://doi.org/10.1016/j.tig.2006.07.008.

Thompson, M.M., Olmo, H.P., 1963. Cytohistological studies of Cytochimeric and tetraploid grapes. Am. J. Bot. 50, 901. https://doi.org/10.2307/2439777.

Tornielli, G., Koes, R., Quattrocchio, F., 2009. The genetics of flower color. In: Gerats, T., Strommer, J. (Eds.), Petunia. Springer New York, New York, NY, pp. 269-299. https://doi.org/10.1007/978-0-387-84796-2 13.

Torregrosa, L., Fernandez, L., Bouquet, a, J-M, B., Pelsy, F., Jm, M.-Z., 2011. Origins and Consequences of somatic variation in grapevine. Genet. Genomics, Breed. Grapes 68-92. https://doi.org/10.1201/b10948-4.

Van Leeuwen, C., Roby, J.P., Alonso-Villaverde, V., Gindro, K., 2013. Impact of clonal variability in Vitis vinifera cabernet franc on grape composition, wine quality, leaf blade stilbene content, and downy mildew resistance. J. Agric. Food Chem. 61, 19-24. https://doi.org/10.1021/jf304687c.

Vannozzi, A., Wong, D.C.J., Höll, J., Hmmam, I., Matus, J.T., Bogs, J., Ziegler, T., Dry, I., Barcaccia, G., Lucchin, M., 2018. Combinatorial regulation of stilbene synthase genes by WRKY and MYB transcription factors in grapevine (Vitis vinifera L.). Plant Cell Physiol. https://doi.org/10.1093/pcp/pcy045.

Vargas, A.M., Vélez, M.D., De Andrés, M.T., Laucou, V., Lacombe, T., Boursiquot, J.M., Borrego, J., Ibáñez, J., 2007. Corinto bianco: a seedless mutant of Pedro Ximenes. Am. J. Enol. Vitic. 58, 540-543.

Vezzulli, S., Leonardelli, L., Malossini, U., Stefanini, M., Velasco, R., Moser, C., 2012. Pinot blanc and Pinot gris arose as independent somatic mutations of Pinot noir. J. Exp. Bot. 63, 6359-6369. https://doi.org/10.1093/jxb/ers290.

Walker, A.R., Lee, E., Bogs, J., McDavid, D.A.J., Thomas, M.R., Robinson, S.P., 2007. White grapes arose through the mutation of two similar and adjacent regulatory genes. Plant J. 49, 772-785. https://doi.org/10.1111/j.1365-313X.2006.02997.x.

Walker, A.R., Lee, E., Robinson, S.P., 2006. Two new grape cultivars, bud sports of Cabernet Sauvignon bearing pale-coloured berries, are the result of deletion of two regulatory genes of the berry colour locus. Plant Mol. Biol. 62, 623-635. https://doi. org/10.1007/s11103-006-9043-9.

Wong, D.C.J., Matus, J.T., 2017. Constructing integrated networks for identifying new secondary metabolic pathway regulators in grapevine: recent applications and future opportunities. Front. Plant Sci. 8, 1-8. https://doi.org/10.3389/fpls.2017.00505.

Wong, D.C.J., Schlechter, R., Vannozzi, A., Höll, J., Hmmam, I., Bogs, J., Tornielli, G.B., Castellarin, S.D., Matus, J.T., 2016. A systems-oriented analysis of the grapevine R2R3-MYB transcription factor family uncovers new insights into the regulation of stilbene accumulation. DNA Res. 23, 451-466. https://doi.org/10.1093/dnares/ dsw028.

Yakushiji, H., Kobayashi, S., Goto-Yamamoto, N., Tae Jeong, S., Sueta, T., Mitani, N., Azuma, A., 2006. A skin color mutation of grapevine, from black-skinned pinot noir to white-skinned pinot blanc, is caused by deletion of the functional VvmybA1 allele. Biosci. Biotechnol. Biochem. 70, 1506-1508. https://doi.org/10.1271/bbb.50647.

Yamakawa, T., Kato, S., Ishida, K., Kodama, T., Minoda, Y., 1983. Production of anthocyanins by vitis cells in suspension culture. Agric. Biol. Chem. 47, 2185-2191. https://doi.org/10.1080/00021369.1983.10865938.

Zhou, Y., Massonnet, M., Sanjak, J.S., Cantu, D., Gaut, B.S., 2017. Evolutionary genomics of grape ( Vitis vinifera ssp. vinifera ) domestication. Proc. Natl. Acad. Sci. Unit. States Am. 114, 201709257. https://doi.org/10.1073/pnas.1709257114.

Zinelabidine, L.H., Haddioui, A., Bravo, G., Arroyo-García, R., Martínez Zapater, J.M. 2010. Genetic origins of cultivated and wild grapevines from Morocco. Am. J. Enol. Vitic. 61, 83-90. 